\title{
Enhancing International Law with Respect to The Protection of Cultural Property in Times of Armed Conflict: A Comparative Analysis
}

\author{
Salwa Youssef Elekyabi \\ Associate Professor \\ Faculty of Law - Zagazig University
}

\begin{abstract}
:
Over the past years, the world has witnessed the loss of many intrinsic and invaluable cultural property during armed conflicts. Looting the invaluable artefacts of the National Museum of Iraq during the U.S invasion in 2003 is an example. More recently, the Islamic State in Iraq and Syria (ISIS) established, in 2015, a Ministry of Antiquities to officially control looting sites and facilitate both trafficking in cultural artefacts and direct selling. Examples on the destruction and other forms of attack against cultural property during armed conflicts are countless and terribly increasing, which demonstrates the failure of international law in protecting cultural property during times of armed conflict.

This issue has been addressed by the international jurisprudence, and many writings attributed the reason for this to poor compliance with the rules of international law or for the rules' failure to provide sufficient protection. This Article claims that the absence of a unified and consistent "legal framework" for the protection of cultural property is another reason for the failure of international law in protecting cultural property during times of armed conflict. To this end, this Article focuses on examining this reason and tracing its impact on the protection of cultural property.

The 1954 Hague Convention for the Protection of Cultural Property in the Event of Armed Conflict along with its two additional protocols, up until the time of writing this article, were representing the main legal instruments devoted exclusively to the protection of cultural property during times of armed conflict. However, protection is also embedded in different subfields of international law as well as in international jurisdiction and international practice. Therefore, this Article will rely
\end{abstract}


(ISSN: 2537 - 0758)

on the 1954 Hague Convention as the basis for cultural property protection, while comparing it with relevant provisions in related subfields of international law, international jurisdiction and international practice.

Accordingly, this article is divided into four parts. Part I exposes key provisions of cultural property protection in the main treaty with emphasis on their effectiveness and fitness for purpose. Part II explores the division of international law with respect to the protection of cultural property in times of armed conflict, with emphasis on the comparison between the main treaty and related subfields of international law. Part III elaborates on how this division affects the interpretation of the term "cultural property" in practice and impacts the applicability of international law.

Keywords: Cultural Property of great importance, World Cultural Heritage, Unlawful Acts Against Cultural Property, Destruction of Cultural Property.

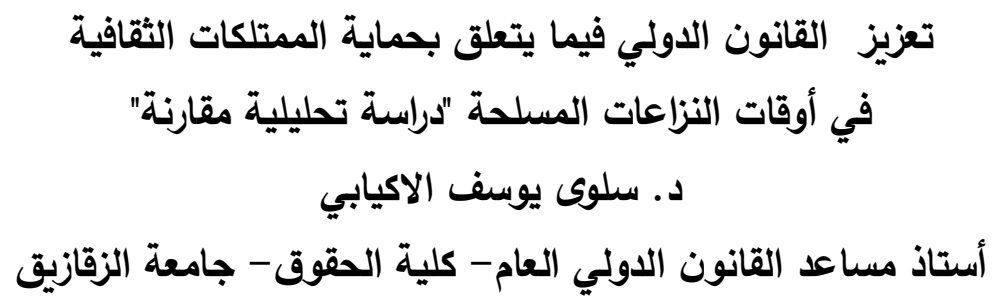

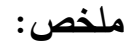

شهد العالم منذ مطلع القرن الحالي فقدان العديد الممتلكات الثقافية "ذات الأهمية الكبرى لتراث الشعوب" في أثناء النزاعات المسلحة. والأمثلة على ذلك عديده، لعل أكثرها بشاعة نهب المتحف الوطني العراقي خلال الغزو الامريكي عام r... وعرض مقتتياته التي لا تقدر بثمن للبيع في السوق السوداء. وفي سوريا تشير التقارير إلى تأسيس داعش في عام 10 ب لوزارة آثار لتنظيم التنقيب غير المشروع عن الآثار

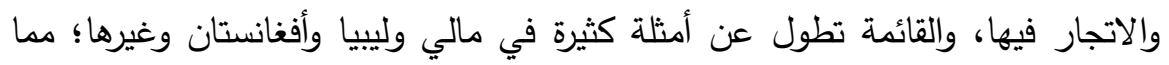
يدلل على إخفاق القانون الدولي في حماية الممتلكات الثقافية في أوقات النزاعات المسلحة، ويثور التساؤل حول سبب هذا الاخفاق وكيفية معالجته. 
Enhancing International Law with Respect to The Protection of Cultural Property in Times of Armed Conflict: A Comparative Analysis

Salwa Youssef Elekyabi

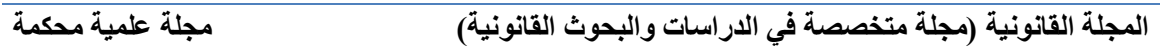

تناول الفقه الدولي تلك المسألة، وأرجعت العديد من الكتابات السبب في ذلك إلى ضعف الامتثال لقواعد القانون الدولي أو قصور تلك القواعد عن توفير الحماية. بيد أنَّ هذا البحث يعرض لسبب آخر وهو عدم وجود "نظام قانوني" موحد ومتسق لحماية الممتلكات

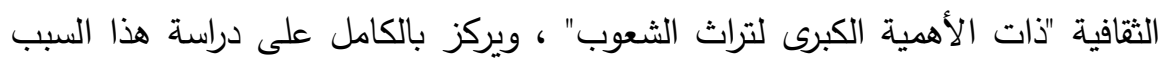
وتتبع تأثيره على حماية الممتلكات الثقافية.

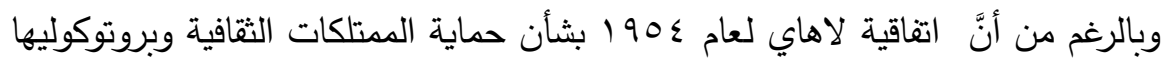

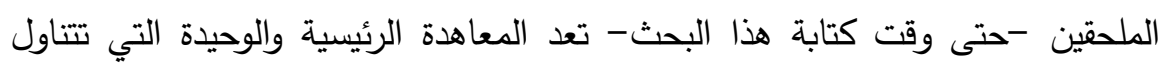

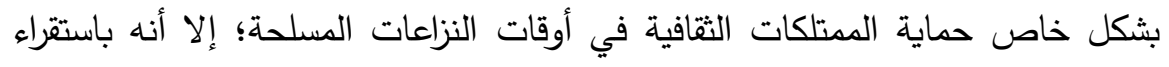

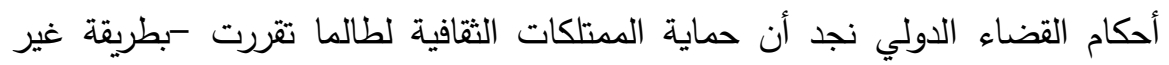
مباشرة - بمناسبة تطبيق وإعمال بعض قواعد فروع القانون الدولي. ولذلك سيتم الاستتاد

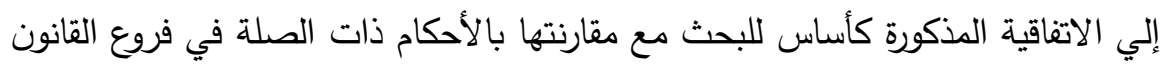
الدولي، واتجاهات القضاء والفقه الدولي، والممارسة الدولية.

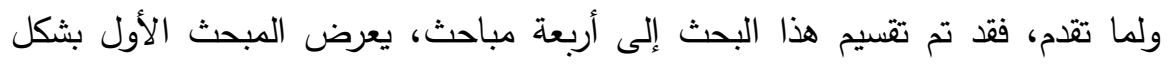

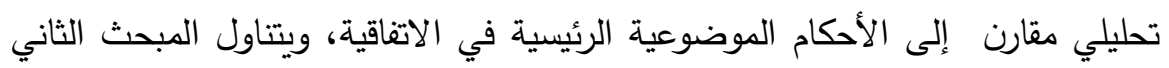

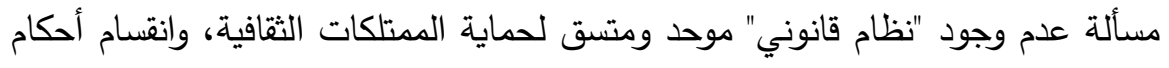

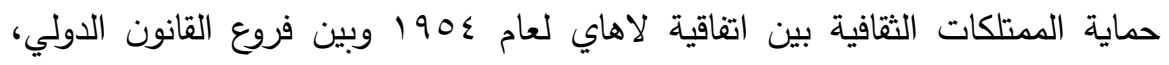

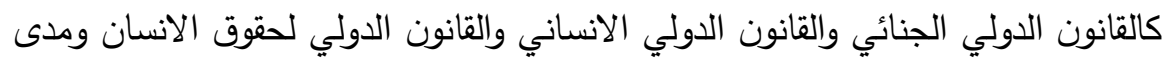

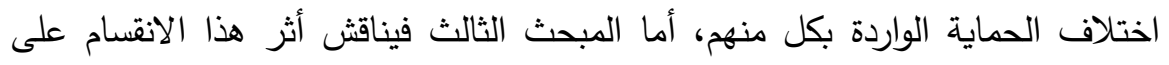
تفسير "مفهوم الممتلكات الثقافية" و"الغرض من الحماية" ونطاق تطبيقها. فيما يختتم المبحث الرابع بملاحظات يقترح فيها استخلاص إطار قانوني لحماية الممتلكات الثقافية "ذات الأهمية الكبرى لتراث الثعوب" من خلال بعض الأدوات المتاحة في القانون الدولي كالتفسير التطوري للمعاهدات الدولية، والممارسة الدولية، وتدوين بعض الدان المبن المبادئ

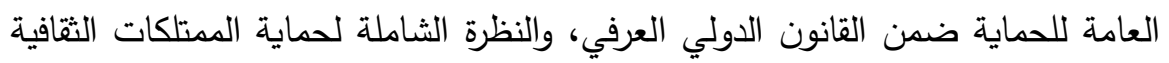

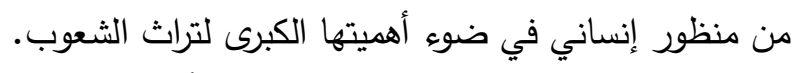
الكلمات المفتاحية: الممتلكات الثقافية ذات الأهمية الكبرى لتراث الثياث الثعوب، الثعب، التراث الثقافي العالمي، الأفعال غير المشروعة ضد المثنات المتلكات الثقافية. 


\section{Enhancing International Law with Respect to The Protection of Cultural Property in Times of Armed Conflict:}

\section{A Comparative Analysis}

\section{Introduction}

Over the past years, the world has witnessed the loss of many intrinsic and invaluable cultural property during armed conflicts. ${ }^{1}$ The conflict in Syria is a notorious example, where invaluable cultural property was irretrievably destroyed, looted, ${ }^{2}$ or massively subjected to illicit trafficking. ${ }^{3}$ In Baghdad, during the U.S invasion in 2003, the National Museum of Iraq was looted and the invaluable artefacts of the museum were displayed on sale in the black market. ${ }^{4}$ This was described later as being one of the worst acts of cultural vandalism during armed conflicts in modern history. ${ }^{5}$ In Mali, during 2012, the extremist armed groups destroyed the mausoleums of Timbuktu, which were registered in the UNESCO World Heritage List. ${ }^{6}$ This destruction was classified later by the International Criminal Court (ICC) as being a war crime. ${ }^{7}$

${ }^{1}$ See, for example, 10 Heritage Sites Lost to Disaster and War, available at: https://artsandculture.google.com/story/10-heritage-sites-lost-to-disaster-andwar/kALyuo79hhrkLQ (all websites in this Article has been checked and last visited on 18 April 2021).

2 According to UNESCO, many museums containing artefacts have been looted. For example: Raqqa Museum and Citadel of Jaabar, Museum of Hama, Museum of Folklore in Aleppo, and Maarrat Museum. The looting has also extended to excavating archaeological sites, such as: Palmyra site, the storehouse of Herqla archaeological site (10 km far from Raqqa), and the Ancient Villages in the north of Syria. More information on the destruction and looting of cultural property in Syria is available on the UNESCO website: http://www.unesco.org/new/en/safeguarding-syrian-cultural-heritage/

${ }^{3}$ Maamoun Abdulkarim, Illicit trafficking of Syrian cultural property, Uniform Law Review, Volume 20, Issue 4, December 2015, pp. 561-567.

${ }^{4}$ It has been estimated that around 15,000 objects were looted from the Iraqi National Museum. The Casualties of War: The Truth about the Iraq Museum, AJA Online, July 2005. Available at: https://www.ajaonline.org/newsletter/110 ${ }^{5}$ Fifteen years after looting, thousands of artefacts are still missing from Iraq's national museum, The Conversation, April 2018. Available at: https://theconversation.com/fifteen-years-after-looting-thousands-of-artefactsare-still-missing-from-iraqs-national-museum-93949

${ }_{6}$ Timbuktu destruction: landmark ruling awards millions to Malians, The Conversation,

August

2017.

Available

at: 


\section{Enhancing International Law with Respect to The Protection of Cultural Property in Times of Armed Conflict: A Comparative Analysis}

Salwa Youssef Elekyabi

Examples on the destruction and other forms of attack against cultural property during armed conflicts are countless and terribly increasing, which demonstrates the failure of international law in protecting cultural property during times of armed conflict. ${ }^{8}$ As noted by commentators and recognized in the jurisdiction of international tribunals, the destruction of cultural property carries profound psychological effects on the local population as well as the international community. ${ }^{9}$ These two facts, the

https://theconversation.com/timbuktu-destruction-landmark-ruling-awardsmillions-to-malians-82540

${ }^{7}$ In 2016, The ICC issued its remarkable and unprecedented judgment of sentencing Ahmad Al-Mahdi to nine years' imprisonment for committing war crimes by having destroyed ten religious and historic sites in Timbuktu, Mali; thus, drawing the attention of the world community to the seriousness of such crimes. See ICC, Prosecutor v Ahmad Al Faqi Al Mahdi, ICC-01/12-01/15, Judgment and Sentence, 27 September 2016. The Court has ordered Al Mahdi to pay $€ 2.7$ million in reparations for his role in the destruction of the UNESCO world heritage site in Timbuktu. Timbuktu destruction: landmark ruling awards millions to Malians, The Conversation, August 2017. Available at: https://theconversation.com/timbuktu-destruction-landmark-ruling-awardsmillions-to-malians-82540

${ }^{8}$ Destruction of cultural heritage is an attack on people and their fundamental rights - UN expert, UN News, 27 October 2016, available at: https://news.un.org/en/story/2016/10/543912-destruction-cultural-heritageattack-people-and-their-fundamental-rights-un\#: :text=UN\%20Podcasts,Destruction\%20of\%20cultural\%20heritage \%20is\%20an\%20attack\%20on,their \%20fundamental $\% 20$ rights $\% 20 \% \mathrm{E} 2 \% 80 \% 93 \% 20 \mathrm{UN} \% 20$ expert\&text $=$ Accord ing\%20to\%20Special\%20Rapporteur\%2C\%20in,protecting\%20human\%20righ ts $\% 20$ and $\% 20$ people.

${ }^{9}$ For example, the Prosecutor of the ICC pointed to the great significance of cultural property to the cultural and spiritual identity of the local people in particular, and the significance of these sites to the international community at large; proclaiming that the destruction of these ancient monuments and shrines has "shocked the conscience of humanity". See: The Prosecutor v Ahmad Al Faqi Al Mahdi: Cultural Property and World Heritage in International Criminal Law, available at:

http://www.culturalheritagelaw.org/resources/Pictures/The $\% 20$ Prosecutor $\% 20 \mathrm{v}$ \%20Ahmad\%20Al\%20Faqi\%20Al\%20Mahdi.pdf. Also see: Jennifer PriceJones, Cultural property protection: a humanitarian concern, February 13, 2020, 
increasing destruction and its impact on people, pose a begging question on the effectiveness of the international law provisions in protecting cultural property during armed conflicts.

The issue of effectiveness of international law in protecting cultural property has been discussed in international scholarly literature, suggesting ways to enhance compliance with international law and better enforcement of it. ${ }^{10}$ In this Article, the effectiveness of international law is handled from a different angle. This Article claims that the structure of the protection of cultural property in international law is among the reasons for its failure to protect cultural property during armed conflict.

The 1954 Hague Convention for the Protection of Cultural Property in the Event of Armed Conflict (the 1954 Hague Convention) along with its two additional protocols, up until the time of writing this article, were representing the core legal instruments devoted exclusively for protecting cultural property during time of armed conflict. ${ }^{11}$ However, in the wide spectrum of Public International Law, the protection of cultural property during armed conflict is also embedded in the main conventions of the International Humanitarian Law (IHL), the International Criminal Law (ICL), and the International Human Rights Law (IHRL). Each of these subfields of international law has its own approach, norms and methods of application. In practical implementation, the 1954 Hague Convention has neither been standing out as a leading instrument that guides all other treaties, nor creating a "framework" for the protection of

available at: https://blogs.icrc.org/law-and-policy/2020/02/13/cultural-propertyprotection-humanitarian/

${ }^{10}$ Patty Gerstenblith, The Destruction of Cultural Heritage: A Crime Against Property or a Crime Against People?, 15 J. Marshall Rev Intell. Prop. L. 336 (2016). Available at:

https://repository.law.uic.edu/cgi/viewcontent.cgi?article=1382\&context=ripl

${ }^{11}$ As of November 2020, the number of states parties to the 1954 Convention was 133 States, 110 of them are also Parties to the First Protocol and 84 of them to the 1999 Second Protocol. The status of ratification is available at: http://www.unesco.org/new/fileadmin/MULTIMEDIA/HQ/CLT/pdf/List-Statemembers-electoral-group-EN-Final-2020.pdf. The full text of the 1954 Convention and the two additional protocols are available at: http://www.unesco.org/new/en/culture/themes/armed-conflict-andheritage/convention-and-protocols/states-parties/ 


\section{Enhancing International Law with Respect to The Protection of Cultural Property in Times of Armed Conflict: A Comparative Analysis}

Salwa Youssef Elekyabi

مجلة علمبة محكمة المجلة القانونية (مجلة متخصصة في الدراسات والبحوث القانونية)

cultural property during armed conflicts. ${ }^{12}$ The International criminal jurisdiction, too, has fluctuated between referring to the 1954 Hague Convention; the rules of the IHL; and the statutes of international criminal tribunals. ${ }^{13}$ This division and the lack of a unified framework for protection has impacted the understanding of "the protection of cultural property" in international law.

To this end, this Article aims to explore the division in the protection of cultural property in international law during armed conflict, by comparing the protection as provided in the main treaty (the 1954 Hague Convention) with related provisions as provided in different instruments and subfields of international law. It also attempts to investigate the division's impact on the understanding of "the protection of cultural property" and its consistent implementation. This is in order to reach a conclusion on the possible ways to enhance the effectiveness of international law with respect to the protection of cultural property in times of armed conflict.

Accordingly, this article is divided into four parts. Part I exposes key provisions of cultural property protection in the main treaty with emphasis on their effectiveness and fitness for purpose. Part II explores the division of international law with respect to the protection of cultural property in times of armed conflict, with emphasis on the comparison between the main treaty and related subfields of international law. Part

${ }^{12}$ According to Mainetti, the term 'framework' is defined by the Oxford English dictionary as "a basic structure underlying a system, concept, or text"; thus, this definition is not matching the protection of cultural property in international law, because the regime of the protection lacks such structure. Mainetti, V. (2004) "De Nouvelles Perspectives Pour La Protection Des Biens Culturels En Cas De Conflit Armé: L'entrée En Vigueur Du Deuxième Protocole Relatif À La Convention De La Haye De 1954." International Review of the Red Cross vol. 86, no. 854, pp. 337-66. In Marina Lostal, Challenges and Opportunities of the Current Legal Design for the Protection of Cultural Heritage During Armed Conflict, International Symposium on Cultural Heritage Protection in Times of Risk: Challenges and Opportunities. Yildiz Technical University, ICOMOS ICORP, Istanbul (Turkey) 2012, pp.328-338. Available at: https://ssrn.com/abstract=2177466.

${ }^{13}$ See for example the ICTY jurisdiction in Kordić and Čerdez, Trial Judgment, at 359-362. Also, in Jokić, Trial Judgment, at 48. 
III elaborates on how this division affects the understanding of the terms "cultural property" and "protection" in practice and impacts the applicability of international law with respect to the protection of cultural property. Part IV concludes with suggestions for enhancement.

\section{The Protection of Cultural Property in Times of Armed Conflict: Key Provisions}

When examining the 1954 Hague Convention and its additional protocol of 1999 along with other related treaties and subfields, four interrelated principles could be derived: (1) the protection of cultural property against destruction and acts of hostility, subject to the exception of imperative military necessity; (2) the prohibition of illicit export, removal, or transfer of ownership of cultural property, and archaeological excavations; (3) the return of cultural property exported from occupied territory; and (4) the prosecution of violations committed against cultural property. Given that the 1954 Hague Convention is the main treaty and the most specialized in this field, this part will expose these four principles as provided in the convention, and then compare them, where applicable, with other related instruments, subfields of international law and international practice.

\section{The protection of cultural property against destruction and acts of hostility}

Under the erga omnes obligation to respect cultural property, ${ }^{14}$ the 1954 Hague Convention states, in Article 4/1, that the High Contracting Parties shall respect cultural property by "refraining from any use of the property and its immediate surroundings or of the appliances in use for its protection for purposes which are likely to expose it to destruction or damage in the event of armed conflict; and by refraining from any act of hostility, directed against such property". Article 4/2 provides also that this obligation is subject to waiver when "military necessity imperatively requires such a waiver". Article $4 / 3$ carries a positive obligation on States to prohibit and prevent any destruction, wilful damage, pillage or vandalism directed against such sites; while, article 4/4 carries a negative obligation on States to refrain from any act of seizure, capture, or

14 This has been stated in Rule 144 "Ensuring Respect for International Humanitarian Law Erga Omnes". IHL Database, Customary IHL, ICRC. Available at: https://ihl-databases.icrc.org/customary$\underline{\mathrm{ihl} / \mathrm{eng} / \mathrm{docs} / \mathrm{v} 1 \text { rul rule144 }}$

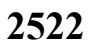




\section{Enhancing International Law with Respect to The Protection of Cultural Property in Times of Armed Conflict: A Comparative Analysis}

Salwa Youssef Elekyabi

مجلة علمبة محكمة المجلة القانونية (مجلة متخصصة في الدراسات والبحوث القانونية)

reprisals against protected objects, as well as, any act of utilizing cultural property and its immediate surroundings for military purposes or any other purpose that is likely to expose it to damage or destruction. In the author's view, this obligation includes also that States should not locate their military equipment or munitions that constitute a legitimate military target near cultural sites, although not clearly stated in the convention.

In this respect, the 1954 Hague Convention distinguishes between two types of protection: General Protection, which applies to a large group of moveable and immoveable objects, including: monuments, archaeological sites, works of art, books, scientific collections, archives, and other buildings including museums, libraries, archival depositories and refuges $;{ }^{15}$ and Special Protection, which is provided to cultural properties of "great importance" that are registered in "the Inter-national Register of Cultural Property under Special Protection" maintained by the Director-General of the United Nations Educational, Scientific and Cultural Organization (UNESCO). ${ }^{16}$ These include: buildings dedicated to religion, art, science, education or charitable purposes and historic monuments.

Under the Second Protocol to the Hague Convention of 1954 for the Protection of Cultural Property in the Event of Armed Conflict 1999 (the 1999 Protocol), ${ }^{17}$ States were obliged to "do everything feasible" to provide general protection, including: minimizing the effects of damage to the lowest, and refraining from attacking property if the attack would cause incidental damage (Article 7/a). With respect to Special Protection, the protocol provided an "enhanced protection" for culture property of great importance, ${ }^{18}$ which mostly mirrors the Special Protection as provided in the 1954 convention.

Both, the Convention and the Protocol, depended on the list system to ensure that special/enhanced protection is provided to the cultural property of great importance. The 1954 Convention established the

${ }^{15}$ Article 1 of the 1954 Convention.

${ }^{16}$ Article 8/6 of the 1954 Convention.

17 The full text of the Protocol is available at: http://portal.unesco.org/en/evphpURL ID $=15207 \& U R L$ DO=DO TOPIC\&URL SECTION=201.html

${ }^{18}$ Article 10 of the 1954 Convention. 
International Register of Cultural Property, which was criticized later on for being unfeasible. ${ }^{19}$ The subsequent protocol revised the listing system by combining aspects of special protection from the 1954 Hague Convention and the criteria for listing cultural property under the 1972 World Heritage Convention, to compose what is known as the International List of Cultural Property under Enhanced Protection. ${ }^{20}$

However, concerns about the effectiveness of the list system have been raised. According to one scholar, the special protection mechanism has never reached its full potential, due to the huge time gap between the updates done on the international register. For example, it has been noted that the time gap between two updates reached 87 years, ${ }^{21}$ in addition to the very limited number of cultural property listed on the 1999 protocol's enhanced protection register ${ }^{22}$ compared to the UNESCO's World Heritage List. ${ }^{23}$ Furthermore, in international criminal courts' practices, the reference has persistently been made to UNESCO's World

${ }^{19}$ Emma Cunliffe and others, The Destruction of Cultural Property in the Syrian Conflict: Legal Implications and Obligations, International Journal of Cultural Property (2016), pp.1-3. Available at: https://papers.ssrn.com/sol3/papers.cfm?abstract_id=2762264.

${ }^{20}$ Article 27/b of the 1999 Protocol.

${ }^{21}$ The International Register was updated in 2015 to include a number of cultural sites in Mexico; prior to that, the last time a State entered a site into the register was in 1978. See: Emma Cunliffe and others, The Destruction of Cultural Property in the Syrian Conflict, op.cit., pp.1-3.

${ }^{22}$ As of February 2021, only 17 sites in total, in 10 states parties, had been listed on the International List of Cultural Property under Enhanced Protection. These comprised one site in Armenia, two sites in Azerbaijan, three in Belgium, one in Cambodia, one in Czech Republic, three in Cyprus, three in Italy, one in Georgia, one in Lithuania, and one in Mali. The full updated list is available at the Convention's website:

http://www.unesco.org/new/en/culture/themes/armed-conflict-andheritage/lists/enhanced-protection/

${ }^{23}$ The world heritage list was established by the Convention concerning the Protection of the World Cultural and Natural Heritage, 16 November 1972, in which states could nominate certain cultural heritage of Outstanding Universal Value to be inscribed on the List. States parties to the Convention are required to protect any listed cultural sites situated on their territory and not take any deliberate measures that might damage listed cultural sites situated on the territory of another State party. The list is available at: https://whc.unesco.org/en/list/. 


\section{Enhancing International Law with Respect to The Protection of Cultural Property in Times of Armed Conflict: A Comparative Analysis}

Salwa Youssef Elekyabi

مجلة علمبة محكمة المجلة القانونية (مجلة متخصصة في الدراسات والبحوث القانونية)

Heritage List when it comes to criminal sanctions for violations. ${ }^{24}$ All these question the effectiveness and the reliability of the list system of the Convention and the Protocol and whether there is still a need for having two separate lists established to serve the same purpose.

The Special Protection includes marking the cultural property with a distinctive emblem (Article 10). According to one scholar ${ }^{25}$ marking particular culture properties with a distinctive emblem may render them to a deliberate targeting, so, in some cases, it may be in the interest of protection not to mark the cultural property. Fortunately, the provision of marking the cultural property with a distinctive emblem is not mandatory. ${ }^{26}$

Article $8 / 2$ of the Convention states that "a refuge for movable cultural property may also be placed under special protection, whatever its location", and when feasible may be transported to a safer place (Article 12). Although the establishment of "safe havens" or "refuges" to preserve endangered movable cultural property in time of conflict had been long envisioned by the 1954 Hague Convention, the practical application of this provision has only been made lately. It started with initiatives by States, such as the "Afghanistan Museum-in-Exile" built by

${ }^{24}$ For example; in the Jokić case, the Trail Chamber noted that being registered in the World Heritage List, the Old Town has a special status which had "been taken into consideration in the definition and evaluation of the gravity of the crime". Also, in Al Mahdi case, the ICC had referred to the status of the destructed mausoleums as being registered in the world heritage list in the Judgment and the Sentence, 27 September 2016, para. 80.

25 Emma Cunliffe and others, The Destruction of Cultural Property in the Syrian Conflict, op.cit., pp.1-3.

${ }^{26}$ For example, it was reported that the Yugoslavian forces had deliberately targeted the marked objects, including the old town of Dubrovnik. Since then, many states have become reluctant to employ the symbol for fear of suffering the same consequences in future armed conflicts. Ashlyn Milligan, Targeting Cultural Property: The Role of International Law, pp.93-106. Available at: https://jpia.princeton.edu/sites/jpia/files/2008-5.pdf. For more see, Jan Hladik, Marking of cultural property with the distinctive emblem of the 1954 Hague Convention for the Protection of Cultural Property in the Event of Armed Conflict, IRRC June 2004 Vol. 86 No 854, pp. 379-387. Available at: https://www.icrc.org/en/doc/assets/files/other/irrc 854_hladik.pdf; 
(ISSN: 2537 - 0758)

Switzerland in $2001,{ }^{27}$ and then was widely accepted and implemented by many States. ${ }^{28}$ In December 2016, the Abu Dhabi Declaration ${ }^{29}$ was issued as the outcome of the conference on "Safeguarding Endangered Cultural Heritage". The Declaration set out two long-term goals: (i) the "creation of an international fund for the protection of endangered cultural heritage in armed conflict"; 30 and (ii) the "creation of an international network of safe havens to temporarily safeguard cultural property endangered by armed conflicts". ${ }^{31}$ In 2017, the UN Security

27 The "Afghanistan Museum-in-Exile" received more than 1,400 Afghan cultural objects and established a complete inventory. In 2006, all the 1,400 objects were successfully restituted to the National Museum of Afghanistan in Kabul, under the umbrella of UNESCO. UNESCO, "Museum-in-Exile: Swiss Foundation Safeguards over 1,400 Afghan Artefacts", 7 October 2000.

${ }^{28}$ For example, The Association of Art Museum Directors, representing the leadership of major art museums in the United States, Canada and Mexico, has issued protocols for safe havens for works of cultural significance from countries in crisis. Association of Art Museum Directors, Protocols for Safe Havens for Works of Cultural Significance from Countries in Crisis, 28 September 2015.

29 International Council on Monuments and Sites (ICOMOS), "Abu Dhabi Declaration on Heritage at Risk in the Context of Armed Conflicts", 3 December 2016, available at: https://tinyurl.com/ybodfemx.

${ }^{30}$ Following the Abu Dhabi Declaration, France, together with the United Arab Emirates, launched a fund, the International Alliance for the Protection of Cultural Heritage in Conflict Areas (ALIPH), based in Geneva, that will take urgent action in emergency cases and contribute to the evacuation and reconstruction of endangered or damaged cultural heritage. Seven countries France, Saudi Arabia, Kuwait, the United Arab Emirates, Luxembourg, Morocco and Switzerland - have pledged contributions, and six others - Italy, the UK, Germany, China, the Republic of Korea and Mexico - have expressed political support for the initiative. With UNESCO acting as a member of the ALIPH board, this effort demonstrates the widespread interest among States in taking active measures to safeguard cultural property and ensure its protection from damage and destruction in armed conflict. Polina Levina Mahnad, Protecting cultural property in Syria: New opportunities for States to enhance compliance with international law?, op.cit., pp. 1037-1074

${ }^{31}$ International Council on Monuments and Sites (ICOMOS), "Abu Dhabi Declaration on heritage at risk in the context of armed conflicts", available at www.icomos.org/en/what-we-do/image-what-we-do/401-heritage-atrisk/8262icomos-adopts-the-abu-dhabi-declaration-on-heritage-at-risk-inthe-context-ofarmed-conflicts . 


\section{Enhancing International Law with Respect to The Protection of Cultural Property in Times of Armed Conflict: A Comparative Analysis}

Salwa Youssef Elekyabi

مجلة علمبة محكمة المجلة القانونية (مجلة متخصصة في الدراسات والبحوث القانونية)

Council adopted Resolution 2347, with an explicit reference to the 2016 Abu Dhabi Declaration, to encourage the UN State Members to establish a network of "safe havens" in their own territories to protect cultural property. ${ }^{32}$ However, in practice, only France and Switzerland did enact legislation to allow the creation of safe havens in their territory for such purposes. ${ }^{33}$ Most States were of the view that safe havens should be created in the concerned country's own territory rather than in other countries for mainly two reasons: first, protecting cultural property of a particular State is that State's own responsibility, and second, States must respect other states' sovereignty and should not interfere in their affairs. $^{34}$

In addition to the establishment of safe havens, UNESCO has urged States, in its recommendation adopted by the 38th General Conference in 2015 , to take steps towards preserving digital copies of documents of great importance that have become endangered due to the armed conflict; however, few States have taken steps towards enforcing this. ${ }^{35}$

The 1954 Hague Convention has also offered respect for the authorized personnel engaged in the protection of cultural property, in consistence with the interests of security and the interests of such property; they shall

${ }^{32}$ For more about the Security Council Resolution 2347 (2017) see: Security Council Condemns Destruction, Smuggling of Cultural Heritage by Terrorist Groups, Unanimously Adopting Resolution 2347 (2017). Available at:

https://www.un.org/press/en/2017/sc12764.doc.htm\#: :text=Unanimously\%20 adopting\%20resolution\%202347\%20(2017)\%2C\%20the\%2015\%2Dmember,gr oups\%20associated\%20with\%20Al\%2DQaida.

${ }^{33}$ For more see: Nikolaus Thaddäus Paumgartner \& Raphael Zingg, The Rise of Safe Havens for Threatened Cultural Heritage, International Journal of Cultural Property, 25(3), 2018, pp. 323-346. Available at:

file:///C:/Users/salwa.elekyabi/Downloads/the-rise-of-safe-havens-forthreatened-cultural-heritage.pdf

34 Polina Levina Mahnad, Protecting cultural property in Syria: New opportunities for States to enhance compliance with international law?, ICRC (2017), 99 (3), pp. 1037-1074. Available at: https://internationalreview.icrc.org/sites/default/files/906 10.pdf

35 Finland has established an archive in Helsinki to store the digitalized documents from Syria. Ministry of Education and Culture, "Endangered Syrian Documents Taken into Safekeeping at the National Archives of Finland", Finland, 2 December 2016. 
be allowed to continue to carry out their duties, even if they fall into the hands of the opposing Party. ${ }^{36}$ Protection is also offered to authorized means of emergency transport against seizure, capture and placing in prize. ${ }^{37}$ However, the protection of employees and defenders of cultural property in the 1954 Hague Convention and the IHL has been, in general, criticized for being inadequate. As an example of inadequateness, the Syria's Directorate General of Antiquities and Museums (DGAM) had lost around fourteen staff members, while conducting operations related to transfer or protection of cultural property. ${ }^{38}$

\section{The imperative military necessity exception}

Although it was controversial during the 1954 Hague Convention negotiations, ${ }^{39}$ the "military necessity" was included as an exception to the general obligation to respect cultural property. Article 4/2 states that the obligation to respect cultural property "may be waived only in cases where military necessity imperatively requires such a waiver". The Convention did not provide any guidance on how to apply the exception; however, the term "imperatively" was included to indicate a high threshold of necessity. ${ }^{40}$ It has been claimed that the lack of clarity in the application of the military necessity exception in the 1954 Hague Convention was due to the unclarity of this exception in law and practice at that time; as, the first codification of the "military objective" in an

${ }^{36}$ Article 15 of the 1954 Convention.

${ }^{37}$ Article 12(3) and 14 of the 1954 Convention.

${ }^{38}$ The Special Rapporteur in the field of cultural rights has referred to incidents from Afghanistan, Mali and Syria, in which cultural property defenders were risking their lives to protect their country's heritage. 'When Cultural Heritage Is Under Attack, Human Rights Are Under Attack' - UN Expert", UN News, 4 March 2016.

${ }^{39}$ Nout Van Woudenberg \& Liesbeth Lijnzaad (eds), Protecting Cultural Property in Armed Conflict: An Insight into the 1999 Second Protocol to The Hague Convention of 1954 for The Protection of Cultural Property in The Event of Armed Conflict (2010), p.243.

${ }^{40}$ Sigrid Van der Auwera, International Law and the Protection of Cultural Property in the Event of Armed Conflict: Actual Problems and Challenges, The Journal of Arts Management, Law, and Society, 43:4, pp. 175-190. Available at: http://dx.doi.org/10.1080/10632921.2013.841114. 


\section{Enhancing International Law with Respect to The Protection of Cultural Property in Times of Armed Conflict: A Comparative Analysis}

Salwa Youssef Elekyabi

مجلة علمبة محكمة المجلة القانونية (مجلة متخصصة في الدراسات والبحوث القانونية)

international convention was elaborated later in the 1977 Additional Protocol I to the 1949 Geneva Conventions. ${ }^{41}$

Under the 1999 Protocol, a narrow definition of the military necessity exception was included, which focused on situations when the culture site became a military objective. The term "military objective" was defined in the Protocol as had been described in the 1977 Additional Protocol I. Article 6/a of the 1999 Protocol stated that a waiver on the basis of imperative military necessity may only be applied when: "(i) the cultural property has, by its function, been made into a military objective; and (ii) there is no feasible alternative available to obtain a similar military advantage to that offered by directing an act of hostility against that objective". These two conditions had to be met together to render the cultural property a legitimate military objective.

With respect to the first condition, the cultural property should, by its function, be made a legitimate military objective. In explaining this condition, the ICTY, in Tadic case, clarified that the mere existence of the property in the battlefield does not justify the attack, but rather its usage and function in hostilities. ${ }^{42}$ Thus, the location of a citadel, for example, near the battlefield is not enough reason to be targeted; but if a party to the conflict has used it as a fortified place to launch attacks, it will be turned into a legitimate military objective. This is consistent with the principle of distinction between civilian/cultural objectives and military objectives, which has long been recognized by States as a principle of customary international law, that is applied in both International Armed Conflicts (IAC) and Non-International Armed

${ }^{41}$ Polina Levina Mahnad, Protecting cultural property in Syria, op.cit., pp.1037-1074.

${ }_{42}$ Kevin Chamberlain, Military necessity under the 1999 Second Protocol, Chapter 3, in Nout Van Woudenberg, Protecting Cultural Property in Armed Conflict : An Insight into the 1999 Second Protocol to the Hague Convention of 1954 for the Protection of Cultural Property in the Event of Armed Conflict, edited by Liesbeth Lijnzaad, BRILL, 2014; Berenika Drazewska, The Human Dimension of the Protection of the Cultural Heritage from Destruction during Armed Conflicts, International Journal of Cultural Property, vol.22 (2015), p.217. 
Conflicts (NIAC). ${ }^{43}$ Within the meaning of this principle, attacks should only target the military objectives; thus, cultural objectives are protected by default from such attacks, with the exception of the imperative military necessity. ${ }^{44}$

The second concurrent condition is that there should be no feasible alternative available to obtain a similar military advantage but to target the cultural property. This means that before directing the attack against cultural property, an evaluation for other alternatives should be done, and the cultural property should be favoured. In other words, if there are two alternative options of destruction, both are of a similar military advantage, but one is a cultural property, then the latter should be protected. $^{45}$

This condition presumes the evaluation between two components, the military advantage in one hand and the cultural property in the other. With respect to the evaluation of the first component "the military advantage", it has been anchored in IHL that the legitimate attacks should aim only at weakening the military forces of the enemy; therefore, any attack beyond this aim is clearly illegitimate and

43 See: Rules of customary international law https://ihldatabases.icrc.org/customary-ihl/eng/docs/v1_rul_rule7. Also, Jean-Marie Henckaerts \& Louise Doswald-Beck eds., Customary International Humanitarian Law (2 volumes), ICRC 2005.

${ }^{44}$ There is also a difference between Military necessity and military objectives. The first justifies the property's destruction, while the latter determines the property's status as a military objective and, therefore, justifies attacks against it. Nobou Hayashi, Requirements of Military Necessity in International Humanitarian Law and International Criminal Law, Boston University International Law Journal 28 (2010), p.113. The shelling of the city of Dubrovnik is an example of destruction with no military objective. It has been concluded that this shelling "did not in any way contribute to the military action and could not in any way be considered necessary in terms of the military objectives pursued". Final Report of the Commission of Experts Established pursuant to Security Council Resolution 780 (1992), Annex, 67-68, paras 285294, S/1994/674 (May 24, 1994), available at:

http://www.icty.org/x/file/About/OTP/un_commission_of_experts_report1994 en.pdf; also, Prosecutor v Strugar, Case No. IT-01-42-T (31 Jan. 2005). Case Information Sheet, "Dubrovnik" Pavle Strugar, available at: http://www.icty.org/x/cases/strugar/cis/en/cis_strugar_en.pdf.

${ }^{45}$ Kevin Chamberlain, Military necessity under the 1999 Second Protocol, op.cit., p.48-49. 


\section{Enhancing International Law with Respect to The Protection of Cultural Property in Times of Armed Conflict: A Comparative Analysis}

Salwa Youssef Elekyabi

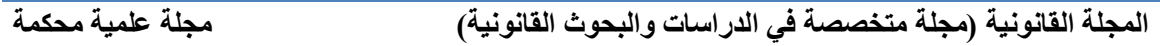

excessive. $^{46}$ This had also been recognized by the International Criminal Tribunal for the Former Yugoslavia (ICTY) Appeals Chamber in Brdanin case. The Chamber had decided to uphold the finding of the lower chamber on the basis that there is "nothing to suggest that destruction provided any kind of advantage in weakening the military forces opposing the Bosnian Serbs, favoured the Bosnian Serb position, or was otherwise justified by military necessity". ${ }^{47}$ So, according to the 1999 Protocol, there has to be a military "advantage" out of destructing cultural property, unlike the 1954 Hague Convention which requires an "imperative military necessity". According to one scholar, the 1999 Protocol, in this respect, has reduced the threshold of the military necessity exception from one of "necessity" to one of "advantage". ${ }^{4}$

The evaluation of the second component "the cultural property", depends on the decision-makers' knowledge about the cultural property's history, value, quality, age and importance to people. Hence, assessing the impact of the attack on the property is not always assumed to be precisely calculated, especially if it is of a less well-known cultural property. In addition, the comparison will definitely differ from situation

${ }^{46}$ As emphasized in the Declaration of Saint- Petersberg: "That the only legitimate object which States should endeavour to accomplish during war is to weaken the military forces of the enemy; That for this purpose it is sufficient to disable the greatest possible number of men; That this object would be exceeded by the employment of arms which uselessly aggravate the sufferings of disabled men, or render their death inevitable; That the employment of such arms would, therefore, be contrary to the laws of humanity". The 1868 Declaration of Saint Petersburg, available at: https://ihldatabases.icrc.org/applic/ihl/ihl.nsf/Treaty.xsp?action=openDocument\&docum entId=3C02BAF088A50F61C12563CD002D663B

${ }^{47}$ The Appeals Chamber held that "the total or partial destruction of the cultural property in question did not offer a definite military advantage to the Bosnian Serb forces”. Brđanin, Appeals Chamber Judgment, IT-99-36-A, 3 April 2007, para.337.

${ }^{48}$ As argued by Forrest, Article 6(a) of the Second Protocol reduces the standard from one of "necessity" to one of "advantage." See: Patty Gerstenblith, The Destruction of Cultural Heritage, op.cit., pp337-389. 
to another, depending on the decision-makers' degree of training and level of knowledge. ${ }^{49}$

Considering the above, the decision to target cultural property based on an evaluation between the military advantage and the cultural property can vary form case to case, because it all depends on a human's own discretion. For example, the military usage of a cultural property might be assessed as temporary and minimal by one person, and substantial by another. The same applies to assessing other alternatives and the necessity to launch an attack on the cultural property. According to one scholar, ${ }^{50}$ the advancement in technological capabilities should be considered by international tribunals when determining the necessity of the attack and whether an excessive force had been used.

Since targeting cultural property is an exception, its application should be limited and its effects on the property should be minimized. In this context, the 1999 Protocol provided certain measures to be ensured, if a decision to target a cultural property was to be taken. First, the Protocol requires States to "refrain to launch any attack which may be expected to cause incidental damage, which would be excessive in relation to the concrete and direct military advantage anticipated",51 and if the attack would cause excessive damages, then it should be suspended or cancelled. ${ }^{52}$ This is known as the principle of proportionality, ${ }^{53}$ which is also recognized by the 1954 Hague Convention. ${ }^{54}$ Based on this principle, the ICTY, in prlic case, found that although the Mostar Bridge

${ }^{49}$ Kevin Chamberlain, Military necessity under the 1999 Second Protocol, op.cit., p.46-47.

${ }^{50}$ Luke Moffett, A Bridge Too Far? Attacks against Cultural Property used as Military Objectives as War Crimes: The Prlić et al. case and the Mostar Bridge, International Criminal Law Review, June 2020, pp.12-13. Available at SSRN: https://ssrn.com/abstract $=3603168$

${ }^{51}$ See: Article 7/c of the second protocol. This Article tracks closely Article 57 of Additional Protocol I to the 1949 Geneva Conventions. See: Jirí Toman, Cultural Property in War: Improvement in Protection, Commentary on the 1999 Second Protocol to the Hague Convention of 1954 for the Protection of Cultural Property in the Event of Armed Conflict, (2009), at 125-27.

${ }_{53}^{52}$ Article $7 / \mathrm{d} /$ ii of the second protocol.

${ }^{53}$ For more on the principle of proportionality see: rules of customary international law, available at: https://ihl-databases.icrc.org/customaryihl/eng/docs/v1_rul_rule14

${ }^{54}$ Article $4 / 1$ of the 1954 convention. 


\section{Enhancing International Law with Respect to The Protection of Cultural Property in Times of Armed Conflict: A Comparative Analysis}

Salwa Youssef Elekyabi

مجلة علمبة محكمة المجلة القانونية (مجلة متخصصة في الدراسات والبحوث القانونية)

had been used by the Muslim forces, and therefore was considered a legal military objective, the Croatian military leaders were found guilty for the excessive destruction of the old Bridge. ${ }^{55}$ The Tribunal found that the aim of destruction wasn't only to cut supplies and transport for the Bosnian Muslim forces, but also to isolate the Muslim civilian population on the right bank of the river. ${ }^{56}$ Therefore, when comparing the military advantage of destructing the Bridge with the impact on civilian population, and with regard to the cultural value of the Bridge, the tribunal concluded that the attack was "disproportionate to the concrete and direct military advantage expected by the destruction of the Old Bridge." 57

Second, if the decision to launch an attack is taken against cultural property under the special/enhanced protection, States should announce advance warning before launching any attacks. ${ }^{58}$ This means that the attacks on these types of cultural properties should not be immediate. Third, the 1999 Protocol requires that the decision to launch an attack should only be made by an "officer commanding a force, the equivalent of a battalion in size or larger". ${ }^{9}$ According to this provision, the decision to target cultural property is limited to those of high-level command officers, who are assumed to have the knowledge and experience to compare between the military advantage and the cultural value of a property. However, officers of lower rank are also allowed, under the Protocol, to take the decision to attack cultural property

55 Prosecutor v Prlic et al., Judgment, 29 May 2013, Vol. II, at 348-49. Available at:

http://www.icty.org/x/cases/prlic/tjug/en/130529-2.pdf.

56 Prosecutor v Prlic et al., Judgment, 29 May 2013, Vol. III, at 459-60, available at:

http://www.icty.org/x/cases/prlic/tjug/en/130529-3.pdf,.

${ }^{57}$ Ibid. The Tribunal held that the Bridge is of "immense cultural, historical and symbolic value" for the Muslim population; though its destruction was that of wanton destruction of cities, towns or villages, or devastation not justified by military necessity under Article 3(b) of the ICTY.

${ }^{58}$ Article 6/d of the second protocol.

59 Article 6/c of the second protocol states that "the decision to invoke imperative military necessity shall only be taken by an officer commanding a force the equivalent of a battalion in size or larger, or a force smaller in size where circumstances do not permit otherwise" 
"where the circumstances do not permit otherwise"; ${ }^{60}$ thus, the decision could be taken from a lower level, which raises the same concern of the degree of training and the level of knowledge of the lower rank officers. Nevertheless, while it is assumed that a high-level command officer would have the sufficient knowledge to assess the military advantage, by virtue of his rank and position as well as his experience in military operations, it is doubtful that he would, by necessary, have the sufficient knowledge about the cultural property's history, value, quality, age and importance to people. Therefore, it has been suggested that when in doubt of the value of cultural property, commanders and other military personnel should act based on the assumption that it is of great importance. Also, in order to avoid any personal responsibility for war crimes, commanders and other military personnel are encouraged to treat all objects, structures and sites on foreign territory as "cultural property" protected by the 1954 Hague Convention and its two protocols and by customary international law. ${ }^{61}$

Overall, the military necessity exception applies only to the obligation to protect cultural property against destruction and acts of hostility. Logically, this encompasses only immovable cultural property such as cultural sites and buildings. Therefore, the prohibition on theft, pillage, vandalism, misappropriation, and reprisals against cultural property is not subject to a military necessity exception and therefore is absolute. ${ }^{62}$ Although, the 1999 Protocol has defined the exception more clearly than the 1954 Hague Convention, mirroring the definition of the 1977 Protocol, it seems that the Convention has provided more stringent legal

${ }^{60}$ Article $6 / \mathrm{c}$ of the second protocol.

${ }^{61}$ Roger O'Keefe and others, Protection of Cultural Property: Military Manual, UNESCO 2016, p. $14 . \quad$ Available at: https://unesdoc.unesco.org/ark:/48223/pf0000246633.

${ }^{62}$ In his Report, the Special Rapporteur in the field of cultural rights has made it clear that the prohibitions on theft, pillage, vandalism, and misappropriation and requisition of cultural property are absolute and cannot be subject to a military necessity exception. The Report also referred to the abusive utilization of the military necessity exception and called upon States to adopt the narrowest possible interpretation that would make any targeting or military use of cultural property "highly exceptional". Report of the Special Rapporteur in the field of cultural rights, A/HRC/31/59 (Feb. 3, 2016), paras. 63-64. Available at: http://www.ohchr.org/Documents/Issues/CulturalRights/A-HRC31-59 en.doc. 


\section{Enhancing International Law with Respect to The Protection of Cultural Property in Times of Armed Conflict: A Comparative Analysis}

Salwa Youssef Elekyabi

مجلة علمبة محكمة المجلة القانونية (مجلة متخصصة في الدراسات والبحوث القانونية)

standards to apply the exception. ${ }^{63}$ Further, the exception is still unclear and unspecific. In addition, generally, the interpretation of the extent to which cultural property can be legitimately attacked is complicated in both the Convention and the Protocol, as both refer to different types of the military necessity exception: "unavoidable", "imperative" and "exceptional"; which has consequently impacted the clarity and the consistency of the jurisprudence of international criminal tribunals in this respect.

There is a consensus in international jurisprudence that the military necessity is an exception that should be narrowly interpreted, ${ }^{64}$ or it will ruin the protection of the cultural property as a whole. ${ }^{65}$ As claimed by one scholar, it is ironic that the invaluable cultural property can be destroyed in application of a convention devoted to the protection of cultural property. ${ }^{66}$ According to another scholar, the military necessity exception was invoked too frequently to the extent that it has become the

${ }^{63}$ Marina Lostal, Challenges and Opportunities of the Current Legal Design for the Protection of Cultural Heritage During Armed Conflict, op.cit., pp.228-238. The definition of military objective is provided in Article 52(2) of Additional Protocol I and considered to be a part of customary international law.

${ }^{64}$ Luke Moffett, A Bridge Too Far? Attacks against Cultural Property used as Military Objectives as War Crimes, op.cit., pp.12-13.

${ }^{65}$ Schwarzenberger suggests that the military necessity exception is an extralegal justification for not complying with the IHL. Pictet is of the view that this exception is the last resort where a party to the conflict faces the impossibility of compliance. McCoubrey sees that military necessity operations as a suspension or exception of the IHL. For more on international jurisprudence with regard to the military necessity exception, See Luke Moffett, A Bridge Too Far? Attacks against Cultural Property used as Military Objectives as War Crimes, op.cit., pp.12-13; General Dwight Eisenhower wrote in his staff orders of 29 December 1943: "The phrase 'military necessity' is sometimes used where it would be more truthful to speak of military convenience or even of personal convenience. I do not want it to cloak slackness or indifference." Emma Cunliffe and others, The Destruction of Cultural Property in the Syrian Conflict, op.cit., pp.1-3.

${ }^{66}$ Maja Sersic, protection of cultural property in time of armed conflict, Netherlands Yearbook of International Law, vol.26 (1996), pp 3-14. p.15 
rule rather than the exception. ${ }^{67}$ In the author's view, the exception of military necessity should be re-examined in light of recent developments in technology and methods of warfare, as well as, precedents of application or non-application of this exception. The practice has proved that in some cases, targeting cultural property could be avoided albeit the attack is legitimate. For example, during the First Gulf War, the United States refrained from targeting Iraqi Aircrafts, which were placed next to invaluable archaeological monuments at the ancient Sumerian site of Ur, though the target was legitimate. ${ }^{68}$ Such an example, in the author's view, reflects the ability to opt to save and not to target the invaluable cultural property even when it is legitimate to be targeted; therefore, this demonstrates that the doctrine of military necessity as perceived in international law should be reconsidered.

\section{The prohibition of illicit pillage, removal, export, transfer of ownership of cultural property, and archaeological excavations}

Prohibiting pillage has been introduced in Articles 28 and 47 of the 1907 Hague Regulations, which is considered as a part of the international customary law. ${ }^{69}$ Article 4/3 of the 1954 Hague Convention obliged States to prohibit acts of pillaging, looting, and theft of cultural sites, as a part of the obligation to respect cultural property. However, this

${ }^{67}$ Yaron Gottlieb, Criminalizing Destruction of Cultural Property: A Proposal for Defining New Crimes under the Rome Statute of the ICC, Penn State International Law Review: Vol. 23: No. 4, (2005), p.859. Available at:

http://elibrary.law.psu.edu/psilr/vol23/iss4/16.

${ }_{68}$ Mary Ellen O'Connell, Occupation Failures and the Legality of Armed Conflict: The Case of Iraqi Cultural Property, Working Paper No. 6, Ohio State University Moritz College of Law, 2004; Ashlyn Milligan, Targeting Cultural Property: The Role of International Law, op.cit, pp.93-106.

${ }^{69}$ As indicated by the Nuremburg International Military Tribunal of 1946, the entire 1907 Hague IV convention is "recognized by all civilized nations and ... regarded as being declaratory of the laws and customs of war", including its provisions protecting cultural property. International Military Tribunal of Nuremberg, Trial Part 22 (22 August-1 October 1946), Judgment, 1 October 1946, p. 497. Rule 41 of the Customary IHL study states that "the occupying power must prevent the illicit export of cultural property from occupied territory and must return illicitly exported property to the competent authorities of the occupied territory". Available at: https://ihldatabases.icrc.org/customary-ihl/eng/docs/v1_rul_rule41 


\section{Enhancing International Law with Respect to The Protection of Cultural Property in Times of Armed Conflict: A Comparative Analysis}

Salwa Youssef Elekyabi

مجلة علمبة محكمة المجلة القانونية (مجلة متخصصة في الدراسات والبحوث القانونية)

obligation binds States to prevent its troops from engaging in such acts. ${ }^{70}$ The ordinary interpretation of this article suggests that the acts of pillage, looting or theft are committed from the local population side or from the troops and it is the responsibility of States to prevent such acts. However, recent developments in armed conflicts demonstrate otherwise. In the conflict in Syria, for example, it has been argued that military parties may have been involved in looting sites. ${ }^{71}$

With regard to export and transfer of ownership, the Convention on the Means of Prohibiting and Preventing the Illicit Import, Export and Transfer of Ownership of Cultural Property 1970 (the 1970 UNESCO convention $)^{72}$ states that "the export and transfer of ownership of cultural property under compulsion arising directly or indirectly from the occupation of a country by a foreign power shall be regarded as illicit"(Article 11). The 1995 UNIDROIT Convention on Stolen or Illegally Exported Cultural Objects has included similar provisions, ${ }^{73}$ focusing on uniting all States' efforts to fight the illicit trafficking of cultural property. ${ }^{74}$ Both conventions have addressed the theft and the export of cultural artefacts occurring during peacetime. Article 9 of the 1999 Protocol has also prohibited acts of illicit export, other removal or

${ }^{70}$ Article 4/3 states that "The High Contracting Parties further undertake to prohibit, prevent and, if necessary, put a stop to any form of theft, pillage or misappropriation of, and any acts of vandalism directed against, cultural property. They shall refrain from requisitioning movable cultural property situated in the territory of another High Contracting Party".

${ }^{71}$ Emma Cunliffe and others, The Destruction of Cultural Property in the Syrian Conflict, op.cit., pp.1-3.

${ }^{72}$ UNESCO, "Illicit Trafficking of Cultural Property: Convention on the Means of Prohibiting and Preventing the Illicit Import, Export and Transfer of Ownership of Cultural Property - 1970", available at: www.unesco.org/new/en/culture/themes/illicit-trafficking-of-culturalproperty/1970-convention/.

${ }_{73}$ The Full text of the 1995 UNIDROIT Convention on Stolen or Illegally Exported Cultural Objects is available at: http://www.unesco.org/new/en/culture/themes/illicit-trafficking-of-culturalproperty/1995-unidroit-convention/

${ }^{74}$ The 1995 UNIDROIT Convention requires that states parties should take preventive measures during peacetime (Arts. 3-7) and specific import and export controls (Art. 9) in the event of the outbreak of armed conflict. 
transfer of ownership of cultural property; however, the reference has been made to circumstances in which one State Party is occupying the territory of another State Party, ${ }^{75}$ and therefore this obligation is confined to these specific types of conflicts.

In practice, looting and illegal trafficking of cultural objects are constituting an important source of fund especially for the armed groups. ${ }^{76}$ In Syria, it is reported that the Islamic State in Iraq and Syria (ISIS) has established a Ministry of Antiquities to officially control looting sites, facilitate trafficking in cultural artefacts and direct selling. ${ }^{77}$ Other reports have indicated that ISIS has imposed taxation on site loots and excavations. ${ }^{78}$ This situation has encouraged organized groups, and even individuals, to carry out both planned and unplanned looting without fear of being caught or punished. Although the amount

${ }^{75}$ Lostal also notes the lack of criminal provisions in international instruments concerning the wholesale looting of sites. Marina Lostal, Challenges and Opportunities of the Current Legal Design for the Protection of Cultural Heritage During Armed Conflict, op.cit., pp.228-238.

${ }^{76}$ Cara Libman, Preserving Culture During War: How to Prevent Terrorist Groups From Profiting From The Sale Of Antiquities, 42 Suffolk Transnat'l L. Rev 365, pp.365- 411.

UNESCO Director-General Condemns the Destruction of the Arch of Triumph in Palmyra - "Extremists are Terrified of History", 5 October 2015; UNESCO, "Director-General of UNESCO Irina Bokova Firmly Condemns the Destruction of Palmyra's Ancient Temple of Baalshamin, Syria", 24 August 2015.

77 This has been confirmed by officials from the US State Department, Homeland Security, the Federal Bureau of Investigation, the US Department of Justice, and the United Nations at a conference held in September 2015 presenting newly declassified documents. See: Emma Cunliffe and others, The Destruction of Cultural Property in the Syrian Conflict, op.cit., pp.1-3. For more see: Yaya J. Fanusie and Alexander Joffe, Monumental Fight: Countering the Islamic State's Antiquities Trafficking, Report of the Foundation for Defense of Democracies (Nov 2015), available at http://www.defenddemocracy.org/content/uploads/documents/Monumental_Fig ht.pdf.

${ }^{78}$ ISIS has legalized the taxation of site looting and created a Ministry of Antiquities to officially control the looting of sites and the sale of objects. Taxes reached up to $20 \%$ on looters in Syria. See: Amr al-Azm, Salam alKuntar and Brian I. Daniels, ISIS' Antiquities Sideline, N.Y. TIMES, (Sept. 2, 2014), http://www.nytimes.com/2014/09/03/opinion/isis-antiquitiessideline.html? $\mathrm{r}=0$. 


\section{Enhancing International Law with Respect to The Protection of Cultural Property in Times of Armed Conflict: A Comparative Analysis}

Salwa Youssef Elekyabi

مجلة علمية محكمة المجلة القانونية (مجلة متخصصة في الدراسات والبحوث القانونية)

of ISIS revenue gained out of trading in looted and stolen artifacts is ultimately unknown, it is directed to fund terrorism and acts of hostility, thus, escalating the armed conflict. ${ }^{79}$

In this sense, looting archaeological sites is not merely "looting"; but it is rather a form of destructing cultural property. The Dura Europos site in Syria is an example, where looting left the site in a near-total destruction status. ${ }^{80}$ In this case, such looting could constitute also the war crime of intentional and targeted destruction. Thus, the proper protection of cultural property should include the prevention of looting, export and illegal excavation of sites done by any party of the conflict, or by individuals, and in all situations irrespective of the classification of the armed conflict.

\section{The obligation to return cultural property illegally exported}

Restitution of cultural property, which has been illegally looted or excavated, is an important tool to close the loop of protection. The restitution conceals the harm, by returning the piece of art to its original place. Although some harms are irrecoverable, such as floor mosaic which loses its fundamental value once detached from its original context; restitution of the movable artefacts is still important in the majority of cases. ${ }^{81}$ The First Protocol to the 1954 Hague Convention obliged States to prevent the exportation of cultural property (Article 1) and to return to the competent authorities of the territory previously occupied, cultural property illegally exported to its territory (Article 3) or legally moved to another State Party for safekeeping (Article 5). ${ }^{82}$

${ }^{79}$ Cara Libman, Preserving Culture During War: How to Prevent Terrorist Groups From Profiting From The Sale Of Antiquities, op.cit., pp.365- 411.

${ }^{80}$ Emma Cunliffe and others, The Destruction of Cultural Property in the Syrian Conflict, op.cit., pp.1-3.

${ }^{81}$ Several treaties were concluded between states to organize the process of returning cultural property; for example, the Treaty of Peace between the Allied and Associated Powers and Italy concluded in 1947 to return cultural property to origin states. The Convention on the Settlement of Matters Arising out of the War and the Occupation adopted in 1952 contains similar obligations.

${ }^{82}$ Article 3 stipulates that: "Each High Contracting Party undertakes to return, at the close of hostilities, to the competent authorities of the territory previously occupied, cultural property which is in its territory, if such property has been 
The 1970 UNESCO Convention clearly prohibits "the export and transfer of ownership of cultural property under compulsion arising directly or indirectly from the occupation of a country by a foreign power" (Article 11) and obliges states to co-operate in facilitating the earliest possible restitution of illicitly exported cultural property including actions of recovery. ${ }^{83}$ However, it has to be noted that these provisions are only applied with regard to the inventoried objects and don't extend to illicitly excavated objects. The 1995 UNIDROIT Convention has expanded the restitution scope of cultural objects, to include those "unlawfully excavated, or lawfully excavated but unlawfully retained" (Article 3/2). It further enabled States to request, from the court or a different competent authority in another State, the return of a cultural object, illegally exported from its territory (Article $5 / 1)$.

In light of recent developments in armed conflicts, there are a number of obstacles that may hinder the treaty law from reaching its full potential. The main challenge is that the inventory of artefacts is a key requirement in claiming cultural objects back to their origin country, as provided by related conventions. ${ }^{84}$ Therefore, the restitution would be almost impossible for the illicitly excavated objects that are taken directly from sites or even the museum collections that are not inventoried. Furthermore, restitution, as provided in related treaties, presumes the existence of amicable diplomatic relations to facilitate the international cooperation in recovering stolen artefacts. This is also difficult to be

exported in contravention of the principle laid down in the first paragraph. Such property shall never be retained as war reparations".

${ }^{83}$ Article 13 states that: "The States Parties to this Convention also undertake, consistent with the laws of each State: (b) to ensure that their competent services co-operate in facilitating the earliest possible restitution of illicitly exported cultural property to its rightful owner; (c) to admit actions for recovery of lost or stolen items of cultural property brought by or on behalf of the rightful owners; (d) to recognize the indefeasible right of each State Party to this Convention to classify and declare certain cultural property as inalienable which should therefore ipso facto not be exported, and to facilitate recovery of such property by the State concerned in cases where it has been exported".

${ }^{84}$ Polina Levina Mahnad, Protecting cultural property in Syria, op.cit., pp.1037-1074. 


\section{Enhancing International Law with Respect to The Protection of Cultural Property in Times of Armed Conflict: A Comparative Analysis}

Salwa Youssef Elekyabi

مجلة علمبة محكمة المجلة القانونية (مجلة متخصصة في الدراسات والبحوث القانونية)

attained in most modern conflicts. ${ }^{85}$ Additionally, to enforce related provisions in treaty law, the responsible individuals must be caught, which is another extremely difficult task. As explained by one scholar, the identity of the looters is largely unknown; some are from the local population, and some are organized groups or armed gangs who work in a larger scale. ${ }^{86}$ Further, it is argued that most cases of smuggling the cultural objects, which were caught by custom officers in many States, ended up by returning the stolen objects without any criminal proceedings. ${ }^{87}$ In all, although the restitution of cultural property is stated in various international instruments, a revisit with regard to their application is needed in light of recent developments in armed conflicts.

\section{Prosecuting crimes against cultural property}

The 1954 Hague Convention stipulated, in Article 28,on prosecuting violations of the Convention, that "the High Contracting Parties undertake to take, within the framework of their ordinary criminal jurisdiction, all necessary steps to prosecute and impose penal or disciplinary sanctions upon those persons, of whatever nationality, who commit or order to be committed a breach of the present Convention". However, in practice, this provision was ineffective; as, it didn't describe the exact offences that could trigger criminal liability and left this issue

${ }^{85}$ Marina Lostal and Emma Cunliffe, Cultural Heritage that Heals, op.cit., p. 250.

${ }^{86}$ Neil Brodie, Syria and its Regional Neighbors: A Case of Cultural Property Protection Policy Failure? International Journal of Cultural Propert, 2015, pp.317-335.

${ }^{87}$ For example, between 1991 and 1998, Canadian customs seized 76 pieces of floor mosaic declared as Lebanese handicrafts. However, expert analysis suggested the pieces had come from western Syria. All were returned to the ownership of Syria in 1999. Also, while more than 2000 objects were discovered in the luggage of incoming air passengers, no prosecutions or convictions were ever reported. Presumably recovery and return were considered an appropriate and sufficient response. Ibid. 
to the domestic laws of the parties. ${ }^{88}$ Therefore, it was unfeasible to depend on the 1954 Hague Convention solely as a ground for triggering prosecution. For example, the law of establishment of the Extraordinary Chambers in the Courts of Cambodia (ECCC) of 2004 had stated that the Chambers have the power to prosecute crimes of "the destruction of cultural property during armed conflict pursuant to the 1954 Hague Convention for Protection of Cultural Property in the Event of Armed Conflict". ${ }^{164}$ According to one scholar, this provision caused difficulties in prosecution, because the court was unable to define the crimes; hence, until 2009, no one was prosecuted for committing crimes falling under the violations of the 1954 convention. ${ }^{89}$

Unlike the 1954 Hague Convention, the 1999 Protocol includes an exact description of violations against cultural property that should be prosecuted. The Protocol stipulates individual responsibility for committing any of the following acts: (a) making cultural property under enhanced protection the object of attack; (b) using cultural property under enhanced protection or its immediate surroundings in support of military action; (c) extensive destruction or appropriation of cultural property protected under the Convention and this Protocol; (d) making cultural property protected under the Convention and this Protocol the object of attack; (e) theft, pillage or misappropriation of, or acts of vandalism, directed against cultural property protected under the Convention. Moreover, the 1999 Protocol obliged Member States to prosecute offenders within its domestic jurisdiction (Article 16) and to commit to the principle to either extradite or prosecute (Article 17). ${ }^{90}$

Within the scope of the statutes of international criminal tribunals, crimes against cultural property have been mentioned as part of the war

${ }^{88}$ Yaron Gottlieb, Criminalizing Destruction of Cultural Property, op.cit., pp. $857-896$.

${ }^{164}$ Article 7 of the Law on the Establishment of the Extraordinary Chambers, with inclusion of amendments as promulgated on 27 October 2004. Available at:

documents/KR_Law_as_amended_27_Oct_2004_Eng.pdf

${ }^{89}$ Jirí Toman, Cultural Property in War, op.cit., at 125-127.

${ }^{90}$ Also, the Additional Protocol I to the Geneva Convention treats the extensive destruction of cultural property as a grave breach, unless they are being used 'in support of the military effort'. See: Luke Moffett, A Bridge Too Far? Attacks against Cultural Property used as Military Objectives as War Crimes, op.cit., pp.12-13. 


\section{Enhancing International Law with Respect to The Protection of Cultural Property in Times of Armed Conflict: A Comparative Analysis}

Salwa Youssef Elekyabi

مجلة علمبة محكمة المجلة القانونية (مجلة متخصصة في الاراسات والبحوث القانونية)

crimes that are committed in both IAC and NIAC. Article 3 of the ICTY statute criminalized the "seizure of, destruction or willful damage done to institutions dedicated to religion, charity and education, the arts and sciences, historic monuments and works of art and science". In Strugar case, the Trial Chamber of the ICTY decided that the accused is found guilty of committing a war crime within the meaning of article 3 (d) of the Statute, asserting that such a conduct constitutes war crime regardless of being committed in the international or non-international armed conflict. ${ }^{91}$ Similarly, under the Rome Statute of the ICC, war crime of destruction of cultural property encompasses "[i]ntentionally directing attacks against buildings dedicated to religion, education, art, science or charitable purposes, historic monuments, hospitals and places where the sick and wounded are collected, provided they are not military objectives", ${ }^{92}$ whether committed in international or non-international armed conflict. ${ }^{93}$

While the ICTY statute considers the actual destruction of cultural property a requisite for establishing war crimes, the ICC statute considers only "directing attacks", regardless of its result, a sufficient requisite to establish war crimes. ${ }^{94}$ Hence, the ICC statute provides, in this sense, two levels of protection: the protection against the attack itself, irrespective of its result; and the protection against the damage or destruction as such. These two levels of protection are seen to be important improvements towards widening the category of criminalized acts against cultural property to encompasses "directing attacks" and "causing damages"; thus, enhancing the protection against destruction. ${ }^{95}$ However, in this article, it has also been noted that the protection against

${ }^{91}$ Roger O'Keefe, Protection of Cultural Property under International Criminal Law, 11 Melbourne Journal of International Law (2010), pp.339-392. Available at: https://ssrn.com/abstract=3496642.

${ }_{92}$ Article 8(2)(e)(iv) of the ICC Statute. The term 'attack' is defined in Article 49(1) of the Additional Protocol I as "acts of violence against the adversary, whether in offence or in defense".

${ }^{93}$ Article 8(2)(b)(ix) of the ICC Statute in case of an IAC and Article $8(2)$ (e)(iv) in case of NIAC.

${ }^{94}$ Nout Van Woudenberg and others, Protecting Cultural Property in Armed Conflict, op.cit., p.243.

${ }^{95}$ Ibid. 
attacks is confined to two limiting conditions. First, the attack must be intentional; therefore, the cases where attacks are launched recklessly or in extreme negligence against cultural property are excluded. As argued by one scholar, the attacks against cultural property, as war crimes, are defined to be intentional, this view should be changed in light of recent developments in armed conflicts to consider acts committed in reckless or willful negligence as war crimes. ${ }^{96}$ In the author's view, the international practice confirms this; for example, the UNSC, with regard to the armed conflict in Syria, has referred in its resolution to both intentional and unintentional destruction of cultural heritage. Second, although the term "military objectives" was mentioned in Rome Statute, both Rome Statute and the ICC Elements of Crimes did not include any definition for "military objectives". Therefore, the traditional definition as recognized in the IHL treaties is applied. Accordingly, by applying both conditions, it turns out that the main elements of the war crime of destruction of cultural property are similar to that of the early Hague Conventions.

With respect to seizing cultural property, the Trial Chamber, in Kordic and Cerkez, considered that the obligation to prohibit the seizure of "institutions dedicated to religion", in particular, is customary. ${ }^{97}$ Similarly, Rome Statute of the ICC criminalized the seizure of the enemy's property unless imperatively demanded by the necessities of war. $^{98}$

Although the Rome Statute was diligent in improving the description of acts constituting war crimes in general, it failed to recognize the usage of cultural property in support of military actions as an act constituting war crime; this is despite being recognized by the 1977 Protocols and in the ICTY jurisprudence as a violation of the protection of cultural property. ${ }^{99}$ Also, in modern armed conflicts, the use of cultural sites as

${ }^{96}$ Patty Gerstenblith, The Destruction of Cultural Heritage, op.cit., pp337-389.

97 Prosecutor v Miodrag Jokić, Trial Judgment, No IT-01-42/1-S, Trial Chamber I, ICTY (18 March 2004) at 46; Dario Kordić and Mario Čerdez, Trial Judgment, No IT-95-14/2-T (26 February 2001) at 36 and 360.

${ }_{98}^{98}$ Articles 8(2)(b)(xiii) and 8(2)(e) (xii) of the Rome Statute.

${ }^{99}$ In the Strugar Case, the Trial Chamber ruled that if the Croatian defenders had defensive military positions in the Old Town of Dubrovnik, it would have been "a clear violation of the World Heritage protected status of the Old Town." See Prosecutor v Strugar, Judgment, ICTY Trial Chamber, at para. 183, Case IT-01-42-T (Jan. 31, 2005). 


\section{Enhancing International Law with Respect to The Protection of Cultural Property in Times of Armed Conflict: A Comparative Analysis}

Salwa Youssef Elekyabi

مجلة علمبة محكمة المجلة القانونية (مجلة متخصصة في الدراسات والبحوث القانونية)

depots and sanctuaries has increased and proved to be a serious threat to the protection of cultural property. ${ }^{100}$ In the author's view, the international courts may be capable of enjoying the discretion to include other acts such as: theft, unlawful appropriation, or utilizing cultural property for military purposes etc. as war crimes. War crimes are defined, in both ICTY and ICC statutes, as "serious violations of the laws and customs". The word "serious violations" hasn't been clearly defined in any international instrument, which indicates, in one author's view, that the acts that constitute war crimes, as provided in the ICTY and ICC statutes, are non-exhaustive. ${ }^{101}$ Therefore, judges enjoy the discretion to widen the scope of acts against cultural property, which are considered as "serious violations", on a case-by-case basis and as long as the acts fulfill the seriousness threshold set by the statute. This is supported by the Appeals Chamber in Tadic case, as the Chamber stated that certain requirements must be fulfilled in an act in order to be promoted to a "serious violation". Among them is that it "must constitute a breach of a rule protecting important values, and the breach must involve grave consequences for the victim". Based on this, it is presumed that any act of violation to the protection of cultural property can fall within the meaning of war crimes, provided that it fulfils a certain level of gravity, as decided by the court on a case-by-case basis.

\section{The Division of Cultural Property Protection in International Law}

The protection of cultural property in time of armed conflict is stated primarily in the 1954 Hague Convention and its two additional protocols. The protection is also embedded within the core treaties of related subfields of international law, namely: the IHL, the ICL and the IHRL. However, although each subfield has its unique approach, in application they all intersect with no clear-cut boundaries. ${ }^{102}$ This part briefly elaborates on this issue.

100 Yaron Gottlieb, Criminalizing Destruction of Cultural Property, op.cit., p.867.

${ }^{101}$ Caroline Ehlert (ed.), Prosecuting the Destruction of Cultural Property in International Criminal Law, Brill 2013.

102 Anne Peters, The refinement of international law: From fragmentation to regime interaction and politicization, International Journal of Constitutional 


\section{Early developments}

Although codifying the protection of cultural property during armed conflicts in a binding treaty is relatively new, the protection per se had long been recognized, as a principle, in religions ${ }^{103}$ and the writings of philosophers and scholars. ${ }^{104}$ In ancient times, plunder and pillage of cultural property were very common during wars. ${ }^{105}$ While plunder was often seen as a legal war booty, pillage including the removal of art and architectural decoration was illegal. ${ }^{106}$ During the middle ages, it was

Law, Volume 15, Issue 3, July 2017, pp. 671-704. Available at: https://academic.oup.com/icon/article/15/3/671/4582635

${ }^{103}$ Islam prohibits wanton destruction of buildings and plunder of towns. In the Prophet Mohammed (PBUH) instructions to the Muslim troops, he said: "Refrain from demolishing the houses of the unresisting inhabitant; destroy not the means of their subsistence, nor their fruit trees and touch not the palm and do not mutilate bodies and do not kill children". Bennoune, K., "As-Salamu Alaykum? Humanitarian Law in Islamic Jurisprudence", (1994) Vol.15, No 2, MICH. J. INT'l L., p. 613. The first Caliph, Abu Bakr Siddiq (632- 634AD), instructed his troops to not molest Christian or Jewish worshipers or their monasteries. François Bugnion, The origins and development of the legal protection of cultural property in the event of armed conflict, Speech, Fiftieth Anniversary of the 1954 Hague Convention for the Protection of Cultural Property in the Event of Armed Conflict. Geneva: ICRC, 2004. Available at: https://www.icrc.org/eng/resources/documents/article/other/65shtj.htm

${ }^{104}$ Vattel wrote in 1758 that certain buildings of "remarkable beauty" should not be destroyed, because its destruction will not add to the strength of the enemy. Rousseau maintained that private property of civilians and public property like education and worship buildings should be spared from hostilities. See: Emer de Vattel, Le Droit des Gens, ou Principes de la Loi Naturelle, appliqués à la Conduite et aux Affaires des Nations et des Souverains, (1758, reprinted 1916), Book 3, ch 9, p.168. Available at: https://oll-resources.s3.useast-2.amazonaws.com/oll3/store/titles/1051/0586-01_Bk.pdf. See also: Rousseau, the Social Contract, (1762, reprinted 1968) at 56-57.

${ }^{105}$ In ancient Greece, for example, sacred sites such as Delphi, Delos and Mount Olympus were recognized as untouchable in the event of armed conflict. No acts of hostility were allowed on these sites. Similar rules are found in many civilizations. See Pierre Ducrey, Guerres et guerriers dans la Grèce antique, Payot, Paris, 1969, p. 243.

106 Jiri Toman, The Protection of Cultural Property in The Event of Armed Conflict: Commentary on The Convention For The Protection of Cultural Property in the Event of Armed Conflict and its Protocol, signed on 14 May 1954 in The Hague, and on other instruments of international law concerning 


\section{Enhancing International Law with Respect to The Protection of Cultural Property in Times of Armed Conflict: A Comparative Analysis}

Salwa Youssef Elekyabi

مجلة علمبة محكمة المجلة القانونية (مجلة متخصصة في الدراسات والبحوث القانونية)

presumed, according to various writings, that works of religious, literary, or artistic nature should be protected against destruction; nevertheless, the legitimate war booty concept continued to exist. ${ }^{107}$ In modern history, the Napoleonic wars stand out as the starkest example on plundering cultural objects during that era. Napoleon moved art works throughout Europe, especially Italy, to Paris in order to pursue his dream of creating the French Empire to be the "New Rome". ${ }^{108}$ After the war had ended, France was forced to return the art works to its origin countries; thus, marking the first restitution for cultural property in modern history. ${ }^{109}$ In all, these early developments manifested the exceptional nature of certain cultural properties and the need for special protection of those properties in times of armed conflict. ${ }^{110}$

The Lieber Code of 1863, a manual that organizes the conduct of soldiers during wartime, was the first legal document that exposed the protection of cultural property in time of armed conflict. ${ }^{111}$ The Lieber

such protection, Dartmouth (1996). Available at:

https://digitallibrary.un.org/record/195557? $\ln =\mathrm{en}$

${ }^{107}$ The writings of Jacob Przyluski in the $16^{\text {th }}$ century and Justin Gentilis, writing at the end of the 17th century and Emmerich de Vattel in the $18^{\text {th }}$ century. Contradictory, Hugo Grotius writing in the early and mid-17th century was not in favor of these principles. For more see: Luke Moffett, A Bridge Too Far? Attacks against Cultural Property used as Military Objectives as War Crimes, op.cit., pp.12-13.

108 At that time, Napoleon's actions were severely criticized by the French artists and architectural theorist Quatremere de Quincy. Quatremere "believed that the best art had a universal quality and therefore could not be possessed but ought to be held in the original context in which it was nurtured". Ashlyn Milligan, Targeting Cultural Property: The Role of International Law, pp.93106. Available at: https://jpia.princeton.edu/sites/jpia/files/2008-5.pdf.

109 At the end of the Napoleonic Wars, the Duke of Wellington and Lord Castlereagh forced the French to give up many of the art works taken from other European nations. In addition, the Duke declined the opportunity to take some of the Italian art works and antiquities back to England. See: Ibid.

${ }^{110}$ Ibid.

${ }^{111}$ The Code was signed and issued during the American Civil War by the US President Abraham Lincoln to the Union Forces of the United States on 24 April 1863. See: The Lieber Code of 1863, Instructions for the Government of Armies of the United States in the Field, Series III, Vol. 3, sec. 124, General 
Code referred to "establishments of education, or foundations for the promotion of knowledge, whether public schools, universities, academies of learning or observatories, museums of the fine arts, or of a scientific character" as a protected property from being a war booty. ${ }^{112}$ Although comprehensive, the Lieber Code was a national legislation, which was signed and issued by the US president of the Union Forces of the United States during the American Civil War. ${ }^{113}$ Therefore, its application was limited to the national level.

The Hague Conventions of 1899 and 1907 mark the first international multilateral treaties, which addresses the protection of cultural property on the international level. ${ }^{114}$ The 1899 Convention prohibited pillage ${ }^{115}$ and obliged armies to take all necessary steps to avoid seizure, destruction, or intentional damage to "religious, charitable, and educational institutions, and those of arts and science" as well as to "historical monuments [and] works of art or science". ${ }^{116}$ The 1907 Hague Convention expanded the protection provided in the 1899 Convention to include, in addition to the prohibition of pillage, seizure

Orders no. 100. (Apr. 24, 1863), available at http://www.civilwarhome.com/liebercode.htm

${ }_{112}$ See Article 34 of The Libre Code. The full text available at: https://ihldatabases.icrc.org/applic/ihl/ihl.nsf/Article.xsp?documentId=C4D7FAB1D847 570EC125641A00581C23\&action=openDocument\&SessionID=DYJDRQQU3 $\underline{\mathrm{W}}$; Also, Sigrid Van der Auwera, International Law and the Protection of Cultural Property in the Event of Armed Conflict, op.cit, pp. 175-190.

${ }^{113}$ For more see: Ana Filipa Vrdoljak, Cultural Heritage in Human Rights and Humanitarian Law (May 8, 2009), International Human Rights and Humanitarian Law, pp.250-302, O. Ben-Naftali, ed., Oxford University Press, 2011, Available at: https://ssrn.com/abstract=1401231.

${ }^{114}$ For full texts of both conventions see: Convention (IV) respecting the Laws and Customs of War on Land and its annex: Regulations concerning the Laws and Customs of War on Land. The Hague, 18 October 1907. Available at:

https://scannedretina.files.wordpress.com/2018/12/Hague-Conventions.pdf, and the Convention (II) with Respect to the Laws and Customs of War on Land and Its Annex: Regulations Concerning the Laws and Customs of War on Land, July 29, 1899, [hereinafter 1899 Hague Convention]. Available at http://www.icrc.org/ihl.nsf/WebPrint/150-FULL?OpenDocument.

${ }_{115}$ Articles 23, 28 and 47 of the 1899 Hague Convention.

${ }^{116}$ Article 56 of the 1899 Hague Convention. 


\section{Enhancing International Law with Respect to The Protection of Cultural Property in Times of Armed Conflict: A Comparative Analysis}

Salwa Youssef Elekyabi

مجلة علمبة محكمة المجلة القانونية (مجلة متخصصة في الدراسات والبحوث القانونية)

and destruction, ${ }^{117}$ three obligations on the besieged: (i) to take all necessary steps, "as far as possible", to avoid causing damage to buildings dedicated to religion, art, science, or charitable purposes ... etc., provided they are not being used for military purposes; (ii) to mark the buildings with a distinctive sign; (iii) to avoid using the buildings for military purposes. ${ }^{118}$ The 1907 Hague Convention has referred to the 1899 Convention, and stated that until a "more complete code of the laws of war has been issued", States should ensure that civilians and combatants remain under the protection of "the principles of the law of nations, as they result from the usages established among civilized peoples, from the laws of humanity, and the dictates of the public conscience" in cases that falls outside of the Convention. ${ }^{119}$

Presently, although the Hague Conventions of 1899 and 1907 have been surpassed by the 1954 Hague Convention and subsequent treaties, their rules are recognized as being part of the Customary International Law ${ }^{120}$ and are still in effect with regard to those few States that are party to them but not party to subsequent treaties. ${ }^{121}$

\section{Specialized Treaties}

${ }^{117}$ Article 28 of the 1899 Hague Convention. The pillage of a town or place is also prohibited under Article 56 of the 1907 Hague Convention.

${ }^{118}$ Article 27 of the 1907 Hague Convention.

${ }^{119}$ Eighth preambular recital of the 1907 Hague Convention.

${ }^{120}$ In 1946, the Nuremburg International Military Tribunal declared that the entire Hague Convention (IV) respecting the Laws and Customs of War on Land was "recognized by all civilized nations and ... regarded as being declaratory of the laws and customs of war", including its paragraphs protecting cultural property. International Military Tribunal of Nuremberg, Trial Part 22 (22 August-1 October 1946), Judgment, 1 October 1946, p. 497. See also: The Legality of the threat or Use of Nuclear Weapons, Advisory Opinion, ICJ Reports (1996) 226, at 256; and Legal Consequences of the Construction of the Wall in the Occupied Palestinian Territory, Advisory Opinion, ICJ Reports (2004) 136, at 172. Also, Prosecutor v Miodrag Jokić, Trial Judgment, Case No IT-01-42/1-S, Trial Chamber I, ICTY, (18 March 2004), at 48.

121 Culture Under Fire: Armed Non-State Actors and Cultural Heritage in Wartime, Geneva Call, October 2018. Available at https://www.genevacall.org/wpcontent/uploads/2019/02/Cultural_Heritage_Study_Final_HIGHRES.pdf 
During World War I, cultural property in Europe was massively harmed. The Louvain library in Belgium was burned and the cathedral of Rheims in France was severely damaged; these damages had occurred as part of the savage burning and looting of towns. ${ }^{122}$ At that time, the effectiveness of the Hague Conventions of 1899 and 1907 was questioned and there was an interest in making a new international convention, yet, none was adopted. ${ }^{123}$

During World War II, the destruction of cultural sites and objects was of a large-scale; it was described as the most extensive destruction in history. ${ }^{124}$ According to one scholar, the destruction of art collections and libraries in Eastern Europe was intentionally and indiscriminately inflicted by the Germans. ${ }^{125}$ At that time, drafting a specialized treaty for the protection of cultural property during armed conflict was a compelling need. This resulted in the adoption of the 1954 Hague Convention. The drafters of the 1954 Hague Convention were influenced by the wide devastation of entire cities full of monuments and cultural heritage during World War II; accordingly, the convention focused on how to limit such destructive practices and prevent them from happening again. ${ }^{126}$ In the same year, the first additional protocol attached to the

${ }^{122}$ For the full discussion of the status of cultural property during the world wars I \& II see; Elizabeth Simpson, Spoils of War (1997), Also; Lynn Nicholas, The Rape of Europa (1994); and Sigrid Van der Auwera, International Law and the Protection of Cultural Property in the Event of Armed Conflict, op.cit., pp. 175-190.

${ }^{123}$ In 1935, the Washington Pact for the protection of Artistic and Scientific Institutions and the Historic Monuments was adopted, which was the only international instrument signed at that time. However, it received a very limited acceptance; it was signed by twenty-one states and ratified by only eleven. The full text and more information about the Treaty on the Protection of Artistic and Scientific Institutions and Historic Monuments (Roerich Pact). Washington, 15 April 1935 are available at: https://ihldatabases.icrc.org/ihl/INTRO/325? OpenDocument

${ }^{124}$ Ashlyn Milligan, Targeting Cultural Property: The Role of International Law, op.cit, pp.93-106.

${ }^{125}$ Ibid.

${ }^{126}$ Jean-Marie Henckaerts, New Rules for the Protection of Cultural Property in Armed Conflict", International Review of the Red Cross, Vol. 81, No. 835, 1999. Available at:

https://www.icrc.org/en/doc/resources/documents/article/other/57jq37.htm 


\section{Enhancing International Law with Respect to The Protection of Cultural Property in Times of Armed Conflict: A Comparative Analysis}

Salwa Youssef Elekyabi

مجلة علمبة محكمة المجلة القانونية (مجلة متخصصة في الدراسات والبحوث القانونية)

convention was drafted too. ${ }^{127}$ The Protocol focused exclusively on the status of movable cultural objects ${ }^{128}$ and mainly on the prevention of the export of cultural objects and the return of the illegally exported ones. ${ }^{129}$

During the Balkan war, the world witnessed again massive destruction of cultural property; therefore, concerns about the effectiveness of the 1954 Hague Convention were then raised. ${ }^{130}$ At that time, two main legal concerns emerged: (i) the conflict in Balkan did not reach the level of "armed conflict"; thus, the committed violations had to be treated as per Article 19 only, which is related to the protection of cultural property during peacetime; and (ii) the convention didn't include a clear description of the exact offences that trigger criminal liability; instead, it left this issue to national laws and, therefore, it was hard to refer to the convention solely for prosecution. ${ }^{131}$ In light of these concerns, the 1999 Protocol was adopted to complement and enhance the protection stated

127 See: The First Protocol (1954) to the 1954 Hague Convention for the Protection of Cultural Property in the Event of Armed Conflict, entered into force on 7 August 1956. [hereinafter: The First Protocol]. Available at: http://www.unesco.org/new/fileadmin/MULTIMEDIA/HQ/CLT/pdf/1954_Prot ocol_EN_2020.pdf

${ }^{128}$ The protection of moveable objects was split off from the main Convention because of the United States objection. Therefore, this issue has been included in a separate protocol to encourage the United States to ratify the main Convention without having to go through argument about the question of movable objects. Patty Gerstenblith, The Destruction of Cultural Heritage, op.cit., pp337-389.

${ }^{129}$ Article (I) of the First Protocol,

${ }^{130}$ For more see: Nout Van Woudenberg \& Liesbeth Lijnzaad (eds), Protecting Cultural Property in Armed Conflict, op cit., p.244.

${ }^{131}$ The jurisdiction of the ICTY has relied on the 1954 Convention and the earlier Hague conventions as evidence of customary international law. For example; Article 27 of the 1907 Hague Regulations, the 1954 Hague Convention, Article 53 of Additional Protocol I, and Article 16 of Additional Protocol II were cited as "sources in international customary and treaty law" to define the elements of the offense in Article 3(d) of the ICTY. See ICTY, Art. 3(d), available at: http://www.un.org/icty/legaldoc-e/basic/statut/statute-feb08e.pdf and Prosecutor v Strugar, IT-01-42-T (31 January 2005). 
in the 1954 Hague Convention. ${ }^{132}$ The Protocol includes provisions on the criminal responsibility of individuals, and further clarification of military necessity principle.

In brief, during times of armed conflict, the core instruments for the protection of cultural property encompass: the 1954 Hague Convention; the First Additional Protocol to the Convention; and the 1999 Protocol. Whereas during peacetime, the protection of cultural property is included in two specialized conventions, adopted under the auspices of the UNESCO. One is the Convention on the Means of Prohibiting and Preventing the Illicit Import, Export and Transfer of Ownership of Cultural Property 1970, which was adopted in response to the increasing devastation and thefts from museums and archaeological sites and exporting the stolen and excavated artefacts to western countries in the late 60 s and early $70 \mathrm{~s} .{ }^{133}$ The Second is the Convention Concerning the Protection of the World Cultural and Natural Heritage of 1972 (the 1972 World Heritage Convention), ${ }^{134}$ that was adopted in response to risks that faced architectonical treasures, particularly, the statue of Abou Simbel in Egypt which had come close to drowning and the paintings from the Renaissance in Venice and Florence which had been damaged after the flood. ${ }^{135}$ Although, the two conventions were mainly designed to apply during peacetime, their application was extended in practice to apply during times of armed conflict as well. ${ }^{136}$

When tracing the sequence of the development of international conventions with regard to the protection of cultural property, it is noted that the central driving force behind their adoption was always the perception that the latest one was outdated and unfit for new

132 See: Serge Brammertz, Kevin C. Hughes, Alison Kipp and William B. Tomljanovich, Attacks against Cultural Heritage as a Weapon of War: Prosecutions at the ICTY", Journal of Criminal Justice, Vol. 14, No. 5, 2016.

${ }^{133}$ UNESCO, "50 years against the fight against the illicit trafficking of cultural goods", The UNESCO Courier, October-December 2020, available at: https://unesdoc.unesco.org/ark:/48223/pf0000374570_eng.

${ }_{134}$ UNESCO, "The Convention Concerning the Protection of the World Cultural and Natural Heritage of 1972, 16 November 1972, available at: https://whc.unesco.org/archive/convention-en.pdf

${ }_{135}$ Marina Lostal, Challenges and Opportunities of the Current Legal Design for the Protection of Cultural Heritage During Armed Conflict, op.cit., p.332.

${ }^{136}$ Ibid. See also: Roger O'Keefe and others, Protection of Cultural Property: Military Manual, op.cit., p. 7. 


\section{Enhancing International Law with Respect to The Protection of Cultural Property in Times of Armed Conflict: A Comparative Analysis}

Salwa Youssef Elekyabi

مجلة علمبة محكمة المجلة القانونية (مجلة متخصصة في الدراسات والبحوث القانونية)

developments in warfare. ${ }^{137}$ This, in the author's view, has made development in the protection of cultural property, over time, more dependent on the circumstances of a certain era than on the holistic view of how the cultural property should be protected. The result is the separate proliferation in norms without a holistic view over the system of protection as a whole, as will be discussed in the coming sections.

\section{The International Humanitarian Law}

Beside specialized treaties, the protection of cultural property during armed conflicts is embedded in other core conventions of IHL. ${ }^{138}$ The 1949 Geneva convention IV relative to the Protection of Civilian Persons in Time of War (the 1949 Geneva convention IV) and the Additional Protocols of 1977, the cornerstone of the IHL, have included few provisions on the protection of cultural property. Article 53 of the 1949 Geneva convention IV prohibits "destruction" of personal property subject to the exception of military necessity; pillaging is also prohibited under Article 33 of the Convention. ${ }^{139}$ In such provisions, the protection of cultural property was included as part of the general protection afforded for civilian objectives.

The absence of a comprehensive protection for the cultural property per se in the core conventions of the IHL has established sort of a dichotomy between the elevated protection of cultural property as defined in the main specialized treaty; and the minimal protection of cultural property as being part of the protection of civilian objects in the IHL. This dichotomy has been widened by the fact that the core treaty of IHL has received more attention, in comparison with the specialized treaty "the

${ }^{137}$ Ibid, p.333

${ }^{138}$ According to Bassiouni, the 1954 Convention should be viewed as part of the development of humanitarian law, which is related to the 1949 Geneva Conventions. See: Cherif Bassiouni, Reflections on Criminal Jurisdiction in International Protection of Cultural Property, 10 SYR. J. INT'L L. \& COM. 281 (1983), at 294-96; also, Kevin Chamberlain, War And Cultural Heritage: A Commentary On The Hague Convention 1954 and Its Two Protocols (2d ed. 2013), at 6 .

${ }^{139}$ As argued by Vrdoljak, the prohibition was limited to "destruction" of cultural property; hence, the Convention allows the requisition or confiscation of the property for military purposes. Ana Filipa Vrdoljak, Cultural Heritage in Human Rights and Humanitarian Law op.cit., pp.250-302. 
1954 Hague Convention". ${ }^{140}$ Further, it took time to recognize the principles of each regime of law in the other. For example, the incorporation of the principles included in the 1954 Hague Convention into the IHL framework has happened only through the adoption of the 1977 Additional Protocols; interchangeably, the incorporation of the principles of the 1977 Additional Protocols into the specific cultural property treaty regime has happened through the 1999 Protocol. The time gaps between adopting principles of each regime into the other enhances the existence of such dichotomy between the protection of cultural property in the IHL and the specialized treaty regime.

The protection of cultural property was introduced in Article 53 of the 1977 Additional Protocol I and Article 16 of the 1977 Additional Protocol II, though, both Articles stated that their application is "without prejudice to the provisions of the Hague Convention for the Protection of Cultural Property in the Event of Armed Conflict of 14 May 1954, and of other relevant international instruments". ${ }^{141}$ Therefore, the primacy in application, in case of normative conflict, is to the 1954 Hague Convention and any other relevant international instruments, among which can be counted the 1999 Protocol. ${ }^{142}$ This primacy supports the distinctiveness of the 1954 Hague Convention or any "other relevant international instruments" as a specialized regime for the protection of cultural property. ${ }^{143}$

${ }^{140}$ Patty Gerstenblith, The Destruction of Cultural Heritage, op.cit., pp337-389.

${ }^{141}$ See: The Protocol Additional to the Geneva Conventions of 1949 and relating to the Victims of International Armed Conflicts 1977 [hereinafter: the 1977 Additional Protocol I]; and the Protocol Additional to the Geneva Conventions of 1949, and relating to the Victims of Non-International Armed Conflicts 1977 [hereinafter: the 1977 Additional Protocol II].

${ }^{142}$ It is worth noting that the resolution 20 (IV) of the Diplomatic Conference on the Reaffirmation and Development of International Humanitarian Law Applicable in Armed Conflicts, Geneva, 1974-1977, adopted by the Diplomatic Conference on 7 June 1977 has affirmed this primacy. Roger O'Keefe and others, Protection of Cultural Property: Military Manual, op.cit., pp.3-4.

${ }^{143}$ In the ICRC commentary on Article 53, it was clarified that while the definition of cultural heritage in the 1977 protocol covers "the cultural or spiritual heritage of peoples", it means property "of great importance to the cultural heritage of every people" in the 1954 Hague Convention. Therefore, it has been concluded that concept of cultural heritage in the Additional Protocols is broader than that of the 1954 Convention. This also supports the idea that the 


\section{Enhancing International Law with Respect to The Protection of Cultural Property in Times of Armed Conflict: A Comparative Analysis}

Salwa Youssef Elekyabi

مجلة علمية محكمة المجلة القانونية (مجلة متخصصة في الدراسات والبحوث القانونية)

\section{The International Human Rights Law}

Within the IHRL sphere, there is a reference to the protection of cultural property in various human rights instruments. The 1948 Universal Declaration of Human Rights states in Article 27 the right for everyone to "freely participate in the cultural life of the community, to enjoy the arts". ${ }^{144}$ Though not legally binding, the moral value of this particular declaration is undoubtful and many provisions of the declaration were introduced in the subsequent two legally binding covenants. The 1976 International Covenant on Economic, Social and Cultural Rights (ICESCR) ${ }^{145}$ has obliged States, in Article 15/1/a, to "recognize the right of everyone to take part in cultural life". The ICESCR Committee has interpreted this article to include states" obligation to "[r]espect and protect cultural heritage in all its forms, in times of war or peace". ${ }^{146}$ Therefore, the IHRL applies in both peacetime and armed conflicts; ${ }^{147}$

specialized treaty of the 1954 convention has its distinctive condensed characteristic. Ana Filipa Vrdoljak, Cultural Heritage in Human Rights and Humanitarian Law op.cit., pp.250-302.

${ }^{144}$ Universal Declaration of Human Rights, 12 October 1948, UN Doc A/810 at 71 (1948).

145 International Covenant on Economic, Social and Cultural Rights, 16 December 1966, 993 UNTS 3.

${ }^{146}$ UN Committee on Economic, Social and Cultural Rights (CESCR), General Comment No. 21, Right of Everyone to Take Part in Cultural Life (Article. 15, Para. 1a of the Covenant on Economic, Social and Cultural Rights), E/C.12/GC/21, 21 December 2009, para. 50.

147 The ICJ held, in its advisory opinion on the Legal Consequences of the Construction of a Wall in the Occupied Palestinian Territory, that the construction of the Wall and its associated regime "impede the exercise by the persons concerned of the right to work, to health, to education and to an adequate standard of living" as per the ICESCR. Therefore, depriving a significant number of Palestinians of their freedom to choose the place of their residence, thus impeding the freedom of movement under Article 12 (1) of ICCPR. Though the situation was clearly classified as occupation. ICJ, Advisory Opinion on the Legal Consequences of the Construction of a Wall in the Occupied Palestinian Territory, 9 July 2004, para. 105; and ICJ, Case Concerning Armed Activities in the Territory of the Congo (Congo v Uganda), 19 December 2005, Judgment, para. 216. 
this overlaps with the IHL, which applies exclusively in times of armed conflict and occupation. ${ }^{148}$

Moreover, while some human rights are derogated during states of emergency, including armed conflicts, certain rights are nonderogable. ${ }^{149}$ According to the Human Rights Committee, these rights include, among other rights, the right to "freedom of thought, conscience and religion". ${ }^{150}$ This right has been interpreted widely in the General Comment No 22 of the ICESCR Committee to encompass a holistic understanding of cultural heritage, including tangible and intangible cultural heritage. ${ }^{151}$ This interpretation was reiterated in the report of the Independent Expert in the Field of Cultural Rights of 2011, which clarified that the cultural rights, including the right of access to and enjoyment of cultural heritage and the right to take part in cultural life, are applicable in times of war and peace. ${ }^{152}$

${ }^{148}$ According to the European Union Guidelines on promoting compliance with international humanitarian law, "IHL is applicable in time of armed conflict and occupation. Conversely, human rights law is applicable to everyone within the jurisdiction of the State concerned in time of peace as well as in time of armed conflict. Thus, while distinct, the two sets of rules may both be applicable to a particular situation". Alexander Orakhelashvili, The Interaction between Human Rights and Humanitarian Law: Fragmentation, Conflict, Parallelism, or Convergence? The European Journal of International Law Vol. 19 no. 1. Available at: https://academic.oup.com/ejil/article/19/1/161/430791

${ }_{149}$ See: Article 4 of the ICCPR; Article 27 of the American Convention on Human Rights, 21 November 1969, in force 18 July 1978, OASTS No 36, 1144 UNTS 123; Article 15 of the Convention for the Protection of Human Rights and Fundamental Freedoms (European Convention on Human Rights or ECHR), 4 November 1950, in force 3 September 1953, ETS 5, 213 UNTS 221. No derogation is permitted under the African Charter on Human and Peoples' Rights, 27 June 1981, in force 21 October 1986, OAU Doc CAB/LEG/67/3 rev 5, 1520 UNTS 217.

${ }^{150}$ See: Article 18 of the UDHR; Article 18(2) of the ICCPR; and Article 9 of the ECHR. Also: General Comment No 22, International Covenant on Civil and Political Rights, 16 December 1966, in force 23 March 1976, GA R es 2200A (XXI), 21 UN GAOR Supp (No 16) at 52, UN Doc A/6316 (1966), 999, UNTS 171 .

${ }^{151}$ Ibid.

${ }^{152}$ See: Report of the Independent Expert in the Field of Cultural Rights, UN. Doc. A/HRC/17/38 and Corr.1, 21 March 2011, para. 79; also, UN Human Rights Council, Resolution 6/1, 27 September 2007. Emma Cunliffe and 


\section{Enhancing International Law with Respect to The Protection of Cultural Property in Times of Armed Conflict: A Comparative Analysis}

Salwa Youssef Elekyabi

مجلة علمبة محكمة المجلة القانونية (مجلة متخصصة في الدراسات والبحوث القانونية)

In addition, it has been stated on different occasions that the destruction of cultural property during armed conflicts violates the IHRL. In the report of the UN Special Rapporteur on Cultural Rights, the destruction of culture heritage was included as a threat to the enjoyment of cultural rights. ${ }^{153}$ Furthermore, the UN Security Council, in its Resolution 2100 of 2013 concerning the situation in Mali, considered the "destruction of cultural and historical heritage" as one of the condemned "abuses and violations of human rights and violations of international humanitarian law". ${ }_{155}^{154}$ This demonstrates the overlap between the IHRL and the IHL. ${ }^{155}$

others, The Destruction of Cultural Property in the Syrian Conflict, op.cit., pp.1-3. Professor Karime Bennoune, the new Special Rapporteur on Cultural Rights for the United Nations Council on Human Rights, elaborates that: "Cultural heritage is significant in the present, both as a message from the past and as a pathway to the future. Viewed from a human rights perspective, it is important not only in itself, but also in relation to its human dimension, in particular its significance for individuals and groups and their identity and development processes. Cultural heritage is to be understood as the resources enabling the cultural identification and development processes of individuals and groups which they, implicitly or explicitly, wish to transmit to future generations". Report of the Special Rapporteur in the field of cultural rights, A/HRC/31/59 (Feb. 3, 2016), available at:

http://www.ohchr.org/Documents/Issues/CulturalRights/A-HRC-31-59 en.doc ${ }_{153}$ See: Report of the Special Rapporteur in the field of cultural rights, $\mathrm{A} / \mathrm{HRC} / 31 / 59$ (Feb. 3, 2016), available at http://www.ohchr.org/Documents/Issues/CulturalRights/A-HRC-31-59 en.doc; Report of the Independent Expert in the Field of Cultural Rights, above note 79, para. 77. On 22 March 2018, the Human Rights Council adopted unanimously resolution $\mathrm{A} / \mathrm{HRC} / \mathrm{RES} / 37 / 17$, which condemned the destruction of cultural heritage and recalled upon all States to "respect, promote and protect the right of everyone to take part in cultural life, including the ability to access and enjoy cultural heritage". Polina Levina Mahnad, Protecting cultural property in Syria: New opportunities for States to enhance compliance with international law? International Review of the Red Cross, Volume 99 Number 906 December 2017, pp.1037-1074. Available at: https://internationalreview.icrc.org/sites/default/files/906 10.pdf

154 See: The United Nations Security Council Resolution No. 2100, S/RES/2100 (April 25, 2013). Available at: 
However, it has been noted that the protection of cultural property in peacetime is limited in comparison with the protection during times of armed conflict. The destruction of the two monumental Buddha statues during the rule of Taliban in Afghanistan (1996-2001), which was presumably a period of peacetime, ${ }^{156}$ has indicated the lack of protection of cultural property during peacetime in international law. Another example, which led to diplomatic tension during 2002 between Saudi Arabia and Turkey is when Saudi Arabia destroyed a 200-year-old Ottoman castle to expand facilities for pilgrims in Mecca. ${ }^{157}$ The UNESCO intervened based on a request from Turkey; however, in the end the castle was demolished. ${ }^{158}$ Again, the international law failed to protect cultural property during a peacetime incident.

According to one commentator, ${ }^{159}$ the failure to protect cultural property during peacetime is due to the division of the threats to such protection into two types: one resulting from armed conflicts and the other occurring during peacetime. This division developed historically and has

http://www.un.org/en/peacekeeping/missions/minusma/documents/mali\%20_2 100 E_pdf.

155 The Military manual suggests compliance with either of them and guarantees compliance with the other Military manual. Roger O'Keefe and others, Protection of Cultural Property: Military Manual, op.cit., p.6

${ }^{156}$ The two monumental Buddha statues that had been beautifully carved into the cliffs at Bamiyan in Afghanistan in the sixth century; the whole valley was inscribed on the UNESCO World Heritage List in 2003. For more information:https://www.pri.org/stories/2015-06-11/they-were-destroyed-

taliban-now-giant-buddha-statues-bamiyan-have-returned-3-d. See also, Christian Manhart, UNESCO's mandate and recent activities for the rehabilitation of Afghanistan's cultural heritage, IRRC June 2004 Vol. 86 No 854, pp.401-411. Available at: https://internationalreview.icrc.org/sites/default/files/irrc 854 manhart.pdf.

157 "Saudi Arabia Bulldozes Over Its Heritage", Time Newsletter. Available at: https://time.com/3584585/saudi-arabia-bulldozes-over-its-heritage/

${ }^{158}$ Later, Saudi Arabia announced its plan to move the castle elsewhere to pacify the situation, though this never happened. Kanchana Wangkeo, Monumental Challenges: The Lawfulness of Destroying Cultural Heritage During Peacetime, 28 Yale J. Int'l L. 183-274. Available at:

https://digitalcommons.law.yale.edu/cgi/viewcontent.cgi?article=1206\&context $=$ yjil

${ }^{159}$ Yaron Gottlieb, Criminalizing Destruction of Cultural Property, op.cit., p.859. 


\section{Enhancing International Law with Respect to The Protection of Cultural Property in Times of Armed Conflict: A Comparative Analysis}

Salwa Youssef Elekyabi

مجلة علمبة محكمة المجلة القانونية (مجلة متخصصة في الدراسات والبحوث القانونية)

been enhanced with time. Protection during times of armed conflict developed independently; received more attention; and notably advanced in comparison with protection during peacetime. According to another scholar, this division between the two laws is false and needs to be superseded. ${ }^{160}$

\section{The International Criminal Law}

The ICL has been designed to hold individual criminal responsibility for grave violations of fundamental interests of the international community, also known as international crimes. ${ }^{161}$ Although an exact definition of the term "international crimes" is still under debate, ${ }^{162}$ core international crimes are widely known as comprising war crimes, crimes against humanity and genocide. ${ }^{163}$ The main sources of the ICL are: the statutes of international tribunals; related international conventions; Customary International Law and the jurisprudence of both international and domestic tribunals. ${ }^{164}$ The ICL and IHL are interconnected, many of the IHL rules and principles have been clarified and developed based on the jurisprudence of international criminal tribunals; ${ }^{165}$ conversely, the

160 Gerhard Hafner, Pros and Cons Ensuing from Fragmentation of International Law, 25 MICH. J. INT'L L. 849 (2004). Available at:

https://repository.law.umich.edu/mjil/vol25/iss $4 / 2$

${ }^{161}$ For more about the definition of International Criminal Law see Robert Cryer, Håkan Friman, Darryl Robinson, Elizabeth Wilmshurst, An Introduction to International Criminal Law and Procedure, Cambridge University Press, Jun $12,2014$.

162 "International Criminal Law", RULAC, Geneva Academy. Available at: https://www.rulac.org/legal-framework/international-criminallaw\#collapse2accord

163 See: The statute of the International Criminal Court. Available at: https://www.icc-cpi.int/resource-library/documents/rs-eng.pdf

164 "International Criminal Law", RULAC, Geneva Academy. Available at: https://www.rulac.org/legal-framework/international-criminal-

law\#collapse2accord

$\frac{165}{165}$ The jurisprudence of international criminal tribunals has greatly contributed to clarifying the rules of the IHL. For example, the ICTY in Tadic case, has clarified the criteria in which a situation may be classified as a noninternational armed conflict. See: "International Criminal Law", How Does Law Protect in War?, ICRC. Available at: https://casebook.icrc.org/glossary/international-criminal-law 
international criminal tribunals depend on the core conventions of the IHL in deciding their judgments. Most importantly, the ICL plays a significant role in prosecuting grave breaches of IHL, thus, closing the loop of the protection placed by the IHL and enhancing deterrence.

As early as 1919, pillage and "wanton destruction of religious, charitable, educational, and historic buildings and monuments" were included as war crimes to be prosecuted by the Sub Commission III on the Responsibilities of the Authors of War and on Enforcement of Penalties for Violations of the Laws and Customs of War. These offences copy similar provisions as in Articles 27, 28, and 56 of the 1907 Hague Regulations. ${ }^{166}$ After World War II, the Nuremberg International Military Tribunal (IMT) was established to prosecute those responsible for committing violations of the laws and customs of war. Article $6 / \mathrm{b}$ of the IMT charter extended its jurisdiction to include "plunder of public or private property, wanton destruction of cities, towns or villages, or devastation not justified by military necessity". ${ }^{167}$ The most notable prosecution in this regard was that of Alfred Rosenberg, ${ }^{168}$ the chief of an educational research institute. The IMT found Rosenberg guilty of "organized plunder of both public and private property through the invaded countries"169 on grounds of collecting more than 21,000 artworks stolen from all over German-occupied Europe and housed them in depots. ${ }^{170}$

${ }^{166}$ Ana Filipa Vrdoljak, Cultural Heritage in Human Rights and Humanitarian Law, op.cit., pp.250-302.

167 Article 6 (b) of the Charter of the International Military Tribunal, Nuremberg annexed to the Agreement by United Kingdom, United States, France and USSR for the Prosecution and Punishment of the Major War Criminals of the European Axis, 8 August 1945, 82 UNTS 279. Available at:

https://www.un.org/en/genocideprevention/documents/atrocitycrimes/Doc.2_Charter\%20of\%20IMT\%201945.pdf

168 Rosenberg was found guilty of plundering and persecuting the Jewish people in Europe as a war crime and crimes against humanity, of which he was sentenced to death. Luke Moffett, A Bridge Too Far? Attacks against Cultural Property used as Military Objectives as War Crimes, op.cit., pp.12-13.

${ }^{169}$ Roger O'Keefe, Protection of Cultural Property under International Criminal Law, op.cit, p.337.

${ }^{170}$ Germans were required to restore plundered art works to their original owners; nevertheless, many art works have never been restored. More on seizing cultural materials during WWII is available at: 


\section{Enhancing International Law with Respect to The Protection of Cultural Property in Times of Armed Conflict: A Comparative Analysis}

Salwa Youssef Elekyabi

مجلة علمبة محكمة المجلة القانونية (مجلة متخصصة في الدراسات والبحوث القانونية)

More recently, in 1993, the ICTY was established while the armed conflict was still ongoing, to attain both punitive and deterrent aims. By that time, the 1954 Hague Convention, which contains provisions on criminalizing the violations of the protection of cultural property, was in force. Despite this, the ICTY Statute criminalized acts relating to destruction and confiscation by copying Article 56 of the 1907 Hague Regulations rather than the 1954 Hague Convention. Article 3/d of the ICTY Statute states that the violations of the laws and customs of war include "[S]eizure, destruction or willful damage done to institutions dedicated to religion, charity and education, the arts and sciences, historic monuments and works of art and science". The interpretation of this article in the court's jurisdiction reflected the overlap between the protection of cultural property per se and the protection of civilian objects as envisaged in the IHL. ${ }^{171}$ For example, in Strugar case the tribunal held that civilian objects enjoy a "similar level of protection as a civilian population". ${ }^{172}$ In addition, the Tribunal, in its judgment with regard to violations of the laws and customs of war arising from deliberate armed attacks against historic places in Bosnia and Herzegovina, has referred to Article 27 of the 1907 Hague Regulations; Article 53 of the 1977 Additional Protocol I; and Article 1 of the 1954 Hague Convention. ${ }^{173}$

The same approach has been embraced by the Rome Statute of the ICC. The Statute borrowed the same language used by the 1907 Hague Convention and the 1949 Geneva Conventions. Article 8/2/b/ix of the Statute, ${ }^{174}$ which is dedicated to the protection of specific types of

https://www.ushmm.org/information/exhibitions/online-exhibitions/specialfocus/offenbach-archival-depot/einsatzstab-reichsleiter-rosenberg-a-policy-ofplunder

$\frac{p}{171}$ Ana Filipa Vrdoljak, Cultural Heritage in Human Rights and Humanitarian Law op.cit., pp.250-302

172 Prosecutor v Pavle Strugar, Rule 98 Motion, No IT-01-42-T, Trial Chamber II, ICTY (21 June 2004), at: 62.

${ }^{173}$ Kordić and Čerdez, Trial Judgment, at 359-362. See also Jokić, Trial Judgment, at 48.

174 Article 8(2)(b)(ix) of the Rome Statute of the ICC states as follows: "Intentionally directing attacks against buildings dedicated to religion, education, art, science or charitable purposes, historic monuments, hospitals 
cultural property, has provided the same level of protection to historic monuments as to "hospitals and places where the wound and sick were collected". This supports the approach of the court to recognize the protection of invaluable cultural property as part of the broad scope of the protection of civilian objects in IHL.

In brief, the protection of cultural property during armed conflicts is mainly articulated in the 1954 Hague Convention and its two protocols. However, this set of treaties is neither establishing an independent framework for protecting cultural property during armed conflicts, nor guiding other treaties in interpreting the protection of cultural property during armed conflicts.

\section{The Impact of the Division of Cultural Property Protection in International Law}

The division of the protection of cultural property in international law between the main treaty and other related subfields of international law has impacted the understanding of the "protection of cultural property" as a whole. In this part of the article, the impact of this division is examined from three sides: the interpretation of the term "cultural property"; the applicability of the scope of protection; and the understanding of the purposes of "protection".

\section{A. Interpreting the Term "Cultural Property"}

The concept of cultural property is one of the most controversial concepts. ${ }^{175}$ The interpretation of the term "cultural property" differs according to the organizing treaty and the legal framework followed by such treaty. In addition, "cultural heritage" is another term, which has been used in some contexts to imply a similar meaning as of cultural property.

\section{Cultural property in specialized treaties}

Article 1 of the 1954 Hague Convention defines cultural property as:

and places where the sick and wounded are collected, provided they are not military objectives". Similar provision is found in Article 27 of the 1907 Convention.

${ }^{175}$ Elizabeth Varner, The Art of Armed Conflicts: An Analysis of the United States' Legal Requirements towards Cultural Property under the 1954 Hague Convention, Creighton Law Review, Vol. 44, 2011, p.8. Available at: https://ssrn.com/abstract=2132059. 


\section{Enhancing International Law with Respect to The Protection of Cultural Property in Times of Armed Conflict: A Comparative Analysis}

Salwa Youssef Elekyabi

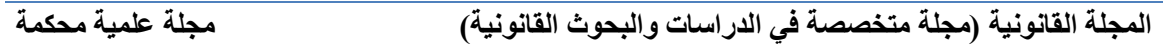

“ a) movable or immovable property of great importance to the cultural heritage of every people, such as monuments of architecture, art or history, whether religious or secular; archaeological sites; groups of buildings which, as a whole, are of historical or artistic interest; works of art; manuscripts, books and other objects of artistic, historical or archaeological interest; as well as scientific collections and important collections of books or archives or of reproductions of the property defined above;

b) buildings whose main and effective purpose is to preserve or exhibit the movable cultural property defined in sub-paragraph (a) such as museums, large libraries and depositories of archives, and refuges intended to shelter, in the event of armed conflict, the movable cultural property defined in sub-paragraph (a);

c) centres containing a large amount of cultural property as defined in subparagraphs (a) and (b), to be known as "centres containing monuments",".

Both additional protocols to the 1954 Hague Convention have referred to the definition of cultural property as stated in Article 1 of the Convention. ${ }^{176}$ Cultural property, within this meaning, includes limited and selective types of cultural property, which have a physical character and of "great importance to the cultural heritage of every people". Article 1 introduces some examples of cultural property such as "monuments of architecture, art or history, whether religious or secular; archaeological sites ...".

The definition in Article 1 has been criticized for being ambiguous, ${ }^{177}$ particularly, the standard "of great importance to the cultural heritage of every people". The term "every people" could be widely interpreted to include all people around the world, or narrowly interpreted to refer to

${ }^{176}$ Article 1 of the First additional protocol of 1954 and Article 1 of the second additional protocol of 1999 .

${ }^{177}$ Elizabeth Varner, The Art of Armed Conflicts: An Analysis of the United States' Legal Requirements towards Cultural Property under the 1954 Hague Convention, op.cit., p.10. 
all people of the State where the property is located. Also, the term "of great importance" is vague and difficult to be assessed. In the author's view, Article 1 should be read together with the preamble, which states that "damage to cultural property belonging to any people whatsoever means damage to the cultural heritage of all mankind". When read together, the term "cultural heritage of every people" would be more likely to be interpreted as including cultural property of great importance to all mankind, as well as, cultural property of great importance within a particular State or a particular group of people. In interpreting the term "of great importance", Scholar Roger O'Keefe suggests that each concerned State should determine what is "of great importance" to it, so it will facilitate recognizing them. ${ }^{178}$

The term "cultural heritage" has been used in the 1972 World Heritage Convention to stand for sites and groups of buildings of an "outstanding universal value". Article 1 of the 1972 World Heritage Convention defines cultural heritage as:

"For the purpose of this Convention, the following shall be considered as "cultural heritage":

- monuments: architectural works, works of monumental sculpture and painting, elements or structures of an archaeological nature, inscriptions, cave dwellings and combinations of features, which are of outstanding universal value from the point of view of history, art or science;

- groups of buildings: groups of separate or connected buildings which, because of their architecture, their homogeneity or their place in the landscape, are of outstanding universal value from the point of view of history, art or science;

- sites: works of man or the combined works of nature and man, and areas including archaeological

sites which are of outstanding universal value from the historical, aesthetic, ethnological or anthropological point of view." "179

${ }^{178}$ Roger O'Keefe, Protection of Cultural Property under International Criminal Law, op.cit., p.359.

179 The 1972 World Heritage Convention has entered into force on 17 December 1975. The number of states parties was 194 as of 23 October 2020. http://whc.unesco.org/pg.cfm?cid=246 


\section{Enhancing International Law with Respect to The Protection of Cultural Property in Times of Armed Conflict: A Comparative Analysis}

Salwa Youssef Elekyabi

مجلة علمبة محكمة المجلة القانونية (مجلة متخصصة في الدراسات والبحوث القانونية)

According to the above definition, the concept of cultural heritage is narrow in comparison with the concept of cultural property. While the cultural property definition as provided in the 1954 Hague Convention encompasses movable and immovable cultural property, cultural heritage as provided in the 1972 World Heritage Convention applies only to immovable cultural property and some limited moveable cultural property or repositories of movable cultural property provided that the repository is itself considered to be a World Heritage Site. ${ }^{180}$ On the other hand, while the cultural property is characterized by its "great importance to the cultural heritage of every people", cultural heritage is very limited to a small selective group of cultural property which are "of outstanding universal value". Within this sense, cultural heritage is a very stringent term compared to cultural property, or as has been described by one scholar, cultural heritage as a term encompasses "la crème de la crème, the best of the best". ${ }^{181}$

Apart from the meaning of cultural heritage as provided in the 1972 World Heritage Convention, the term "Heritage" itself is used to express a "form of inheritance to be kept in safekeeping and handed down to future generations". ${ }^{182}$ Different conventions have referred to "heritage" to indicate varied categories of heritage, including: tangible cultural heritage; intangible cultural heritage, such as: oral traditions, performing arts, rituals; underwater cultural heritage, such as: shipwrecks, underwater ruins and cities; and Natural heritage, which includes natural

${ }^{180}$ Micaela Frulli, The Criminalization of Offences against Cultural Heritage in Times of Armed Conflict: The Quest for Consistency, 22 EUR. J. INT'L L. (2011), pp.203-205; Manlio Frigo, Cultural property $v$ cultural heritage:

A "battle of concepts" in international law?, IRRC June 2004 Vol. 86 No 854, pp.367-378. Available at: https://www.cambridge.org/core/journals/international-review-of-the-redcross/article/abs/cultural-property-v-cultural-heritage-a-battle-of-concepts-ininternational-law/DF36EBF545EAD1BEC9053899795922F3

${ }^{181}$ Marina Lostal, Challenges and Opportunities of the Current Legal Design for the Protection of Cultural Heritage During Armed Conflict, op.cit., pp.228238.

182 Janet Blake, On defining the cultural heritage, International and Comparative Law Quarterly, Vol. 49, 2000, p. 61. Referred to in: Manlio Frigo, Cultural property v cultural heritage: A "battle of concepts" in international law?, IRRC June 2004 Vol. 86 No 854. 
sites with cultural aspects such as cultural landscapes, physical, biological or geological formations. ${ }^{183}$

Both terms, cultural property and cultural heritage, are being used in legal scholarship of international law interchangeably. ${ }^{184}$ In this Article, the term "cultural property" is being used to signify the meaning as included in the 1954 Hague Convention.

\section{Cultural property in IHL and ICL}

Within the IHL sphere, the 1949 Geneva Convention IV did not refer directly to cultural property; although, it clearly protected "personal property" against destruction. Moreover, the 1977 Additional Protocols didn't include a definition for cultural property; however, they provided a general protection of places used by civilians, such as: places of worship, schools and houses, in addition to specific protection for cultural heritage in respect of historic monuments, works of art and places of worship which "constitute the cultural or spiritual heritage of peoples". 185

Within the scope of protection in the 1949 Geneva Convention IV and the 1977 Additional Protocols, cultural property protection is tied to the principle of distinction between civilian and military objective. ${ }^{186}$ According to this principle, legitimate attacks should only target the military objectives and avoid the civilian objectives. Civilian objective is

183 For example: the 1969 European Convention on the Protection of the Archaeological Heritage; the 1985 Convention for the Protection of the Architectural Heritage of Europe; UNESCO Convention for the Protection of Underwater Cultural Heritage of 2 November 2001; the UNESCO Convention for the Safeguarding of the Intangible Cultural Heritage and the UNESCO Declaration concerning the Intentional Destruction of Cultural Heritage, both of 17 October 2003. For more on the distinction between cultural property and cultural heritage see: Lyndel V. Prott and Patrick J. O'Keefe, "Cultural Heritage" or "Cultural Property"?, available at: https://www.cambridge.org/core.

${ }^{184}$ Patty Gerstenblith, The Destruction of Cultural Heritage, op.cit., p.338

${ }^{185}$ Article 53/a of the 1977 Additional Protocol I.

${ }^{186}$ Similar to Article 48 (principle of distinction); Article 57 (principle of proportionality) of the Additional Protocol I. 


\section{Enhancing International Law with Respect to The Protection of Cultural Property in Times of Armed Conflict: A Comparative Analysis}

Salwa Youssef Elekyabi

مجلة علمبة محكمة المجلة القانونية (مجلة متخصصة في الدراسات والبحوث القانونية)

defined as "objects that are not military objectives", ${ }^{187}$ which includes immovable objectives such as hospitals, due to the latter's "human cargo" or importance in providing services to civilians. Therefore, these types of cultural property lose their protection when "civilians are not within their confines or when their services are no longer in need". ${ }^{188}$ In this sense, hospitals and schools enjoy the same level of protection as historical monuments as long as their destruction affects civilians' lives. ${ }^{189}$ In contrast, cultural property protection within the meaning of the 1954 Hague Convention remains irrespective of the presence of civilians within its borders or their need for such property to get a particular service. ${ }^{190}$

According to Gerstenblith, the divergence in interpreting the term "cultural property" and its associated protection between the 1954 Hague Convention and the IHL has its roots in the distinction between the Law of Armed Conflicts and the IHL. ${ }^{191}$ The Geneva Conventions of 1949 were adopted as being a part of the IHL, rather than a part of the law of armed conflict. These two laws, although sharing the same scope of application, are different in aims. While the IHL aims at protecting human life and making wars more humanitarian, the Law of Armed Conflicts focuses on exigencies of warfare and military objectives. This dichotomy between the Law of Armed Conflicts and the IHL was terminated by adopting the 1977 Additional Protocols. Now, both laws are considered synonymous; ${ }^{192}$ however, at the time of adopting the 1954 Hague Convention, this dichotomy was still there and most likely

187 “The Customary International Law”, Practice Relating to Rule 9. Definition of Civilian Objects, the IHL Database of the ICRC, available at: https://ihldatabases.icrc.org/customary-ihl/eng/docs/v2_rul_rule9

${ }^{188}$ Yaron Gottlieb, Criminalizing Destruction of Cultural Property, op.cit., at: 865

${ }^{189}$ Article 8(2)(b)(ix) of the Rome Statute of the ICC.

${ }^{190}$ Yaron Gottlieb, Criminalizing Destruction of Cultural Property, op.cit., pp.857-896.

${ }^{191}$ Patty Gerstenblith, The Destruction of Cultural Heritage, op.cit., pp337-389.

${ }^{192}$ Toman characterizes the law of armed conflict as "situated halfway between military necessity and the principles of humanity and chivalry which both determine the formation and application of the law." Jiri Toman, The Protection of Cultural Property in The Event of Armed Conflict, op.cit., at 73. 
the 1954 Hague Convention aimed to be a part of the Law of Armed Conflicts, rather than the IHL. ${ }^{193}$

In brief, the concept of cultural property in the 1954 Hague Convention is distinct from the concept in the 1949 Geneva Conventions and the 1977 Additional Protocols, mainly in two ways: first, the 1954 Hague Convention distinguishes cultural property from other types of property based on their intrinsic and symbolic value to mankind, rather than their association with civilians; second, while the 1954 Hague Convention encompasses both moveable and immoveable property, the 1949 Geneva Conventions and the 1977 Additional Protocols focus mainly on legitimate attacks and, thus, basically deal with immovable objects. ${ }^{194}$

Within the ICL sphere, criminalizing the destruction of cultural property has been included in various statutes of international tribunals as well as the statute of the ICC; however, the term "cultural property" hasn't been clearly defined in any of these statutes. Instead, the reference has been made to the meaning of cultural property as provided in the 1907 Hague Convention and the 1949 Geneva Conventions, which interpret the term "cultural property" in light of the principle of distinction. Therefore, the term "cultural property", as envisaged in the ICL, encompasses civilian property, such as: the institutions dedicated to religion, charity and education, the arts and sciences, as well as, the historic monuments and works of art and science that may have a great importance to humankind. Despite this, the jurisprudence of the international criminal tribunals also has in some cases referred to the meaning of "cultural property" as provided in the 1954 convention, which has led to an inconsistency in interpreting the term "cultural property". 195

In Čerkez case, the ICTY Trail Chamber considered that educational institutions are property of great importance. It explained that "educational institutions are undoubtedly immovable property of great importance to the cultural heritage of peoples, in that they are without exception centres of learning, arts, and sciences, with their valuable

193 Ibid.

${ }^{194}$ Little reference to the protection of moveable cultural property was included in the 1949 conventions, with regard to the protection of the enemy's property, regardless of its unique cultural value.

${ }^{195}$ Luke Moffett, A Bridge Too Far? Attacks against Cultural Property used as Military Objectives as War Crimes, op.cit., pp.12-13. 


\section{Enhancing International Law with Respect to The Protection of Cultural Property in Times of Armed Conflict: A Comparative Analysis}

Salwa Youssef Elekyabi

مجلة علمبة محكمة المجلة القانونية (مجلة متخصصة في الدراسات والبحوث القانونية)

collections of books and works of arts and science". ${ }^{196}$ However, the Appeals Chamber distinguished between the protection of civilian property; cultural property; and cultural property "of great importance". With respect to the latter, the Appeals Chamber stated that these are "objects whose value transcends geographical boundaries, and which are unique in character and are intimately associated with the history and culture of a people". ${ }^{197}$ Therefore, in this sense, educational institutions, as described by the Trail Chamber in Cerkez case, are not cultural property of great importance. This contrasts with the way the Iraqi Special Tribunal handled this issue in the case against Hussein Rashid and Ali Hassan al-Majid, who were convicted for intentionally destroying 1,344 Kurdish schools and over 2,027 mosques. The Tribunal recognized such property as cultural rather than civilian, although with no emphasis on the requirement of being of great importance. ${ }^{198}$

In all, interpreting the term "cultural property" seems to be unclear in international criminal jurisprudence. It has been concluded by one scholar that the protection of cultural property in ICL seems to "cherrypick from Hague and Geneva Law, but has broad normative elements of the importance of cultural property to communities and peoples". ${ }^{199}$

\section{B. Applicability}

With recent developments in weapons technology and means of communication and warfare, ${ }^{200}$ actors other than States, also known as

${ }^{196}$ Kordić and Čerkez, Trail Chamber Judgment IT-95-14/2-T 21 February 2001, para.360.

${ }^{197}$ Kordić and Čerkez, Appeals Chamber Judgment IT-95-14/2-A 17 December 2004, para.91.

${ }^{198}$ Article 13(b)(10), Statute of the Iraqi Special Tribunal. Iraqi High Tribunal Trial Chamber, No 1/C Second/2006, 2007 June 24, and Appellate Chamber, 4 September 2007.

${ }^{199}$ Luke Moffett, A Bridge Too Far? Attacks against Cultural Property used as Military Objectives as War Crimes, op.cit., pp.12-13.

${ }^{200}$ In Heyns' report, a concern had been raised over the advanced technology reaching the hands of terrorist groups or other non-state entities, especially after Hezbollah claimed in 2012 its responsibility for launching a reconnaissance aircraft and a fighter drone ( Shahid-129) manufactured in Iran, which had been shot down by Israel after flying 25 miles inside the occupied territories. See: Report of the Special Rapporteur on extrajudicial, summary or arbitrary 
Armed Non-State Actors (ANSA), ${ }^{201}$ have been involved in armed conflicts and have become a "party" in most of modern conflicts. This involvement, along with other certain requirements, ${ }^{202}$ turns the conflict into a NIAC. The Appeals Chamber of the ICTY in Tadić case has defined the NIAC as that which exists whenever there is a "protracted armed violence between governmental authorities and organized armed groups or between such groups within a State"; unlike IAC, which "exists whenever there is a resort to armed force between States". ${ }^{203}$ Today, most armed conflicts fall within the description of NIAC. ${ }^{204}$

executions, Christof Heyns, Human Rights Council Twenty-third session, 9 April 2013. Available at:

https://www.law.upenn.edu/live/files/3888-heyns-christof-report-of-thespecial-rapporteur

${ }^{201}$ An armed non-state actor is defined as "any armed actor with a basic structure of command operating outside state control that uses force to achieve its political or allegedly political objectives. Such actors include armed groups, rebel groups and non-internationally recognized governments". Armed NonState Actors and Landmines, Vol 1: A Global Report Profiling NSAS and their Use, Acquisition, Production, Transfer and Stockpiling of Landmines, PSIO Program for the Study of the International Organization(s) and Geneva Call. Available at: https://www.genevacall.org/wp-content/uploads/2019/02/5.pdf

${ }^{202}$ Article 1 of the 1977 Additional Protocol. This is by the ICTY, as the court clarified that "These cases highlight the principle that an armed conflict can exist only between parties that are sufficiently organized to confront each other with military means...Such indicative factors include the existence of a command structure and disciplinary rules and mechanisms within the group; the existence of a headquarters; the fact that the group controls a certain territory; the ability of the group to gain access to weapons, other military equipment, recruits and military training; its ability to plan, coordinate and carry out military operations, including troop movements and logistics; its ability to define a unified military strategy and use military tactics; and its ability to speak with one voice and negotiate and conclude agreements such as cease-fire or peace accords". Prosecutor v Haradinaj, Case No. IT-04-84-84-T, 3 April 2008, para. $' \cdot$. Also, ICTY Prosecutor v Boskoski, Case No. IT-04-82, 10 July 2009, para. 175

${ }^{203}$ ICTY, Prosecutor v Dusko Tadić, Appeals Chamber, Decision on the Defence Motion for Interlocutory Appeal on Jurisdiction, IT-94-1, 2 October 1995, §70, http://www.icty.org/x/cases/tadic/acdec/en/51002.htm

${ }^{204}$ According to the War report of 2018, the number of active IAC is 7, while the number of the NIAC is 60. Aneesa Bellal, The War Report: Armed 


\section{Enhancing International Law with Respect to The Protection of Cultural Property in Times of Armed Conflict: A Comparative Analysis}

Salwa Youssef Elekyabi

During the time of adopting the 1954 Hague Convention, the landmark treaty in the field, and the 1949 Conventions, the core treaty of the IHL, armed conflicts were mostly of an international character. Accordingly, these conventions were mainly designed to be applied in times of IAC, with very limited scope of application during peacetime or times of NIAC. Although it has been held by the ICTY in 2003 that the application of all main principles of humanitarian law, originally meant for IAC, are also applicable during NIAC, ${ }^{205}$ the question remains about the effectiveness of the application of the provisions of treaties, that were originally designed to be applied during IAC, on cases of NIAC and during peacetime.

\section{Peacetime and Time of Armed Conflict}

The 1954 Hague Convention used the term "safeguarding" to refer to actions taken by a State Party during peacetime to protect its own cultural property, while the term "protecting" is used, when referring to actions taken by a State Party once an armed conflict has broken out. During peacetime, under the obligation to safeguard cultural property, Article 3 of the Convention obliged States Parties to safeguard cultural property located within their territory from "the foreseeable effects of an armed conflict". The measures to be taken by States to safeguard cultural property during peacetime, as per Article 7/2, include introducing the related provisions into their military regulations or instructions; fostering spirit of respect for the culture and cultural property of all peoples within their troops; and establishing within their armed forces, services or specialist personnel whose purpose will be to secure respect for cultural property. Similarly, Article 30/3/a of the 1999 Protocol requires States Parties, as appropriate, to incorporate into their military regulations "guidelines or instructions" on the protection of cultural property during times of armed conflict.

The 1970 UNESCO Convention is applicable during both times of armed conflict and peace; the 1972 World Heritage Convention was

Conflicts in 2018. Available at: https://www.geneva-academy.ch/joomlatoolsfiles/docman-files/The\%20War\%20Report\%202018.pdf

${ }^{205}$ See: Decision on Interlocutory Appeal Challenging Jurisdiction in Relation to Command Responsibility, Prosecutor v Hadzihasanovic et al., ICTY, Appeals Chamber, 16 July 2003. 
mainly designed to apply during peacetime, yet, it also applies during armed conflicts. However, the incident of destroying the two monumental Buddha statues in Afghanistan has pointed to the failure of the latter treaty along with related rules of the IHRL to protect cultural property during peacetime, and has urged the international community to take steps toward more enhancement. For example, the UN General Assembly issued an immediate resolution that called on Taliban to protect the country's cultural heritage. Most importantly, the UNESCO adopted its Declaration concerning the Intentional Destruction of Cultural Heritage on October 17, 2003. ${ }^{206}$ The Declaration is applicable during peacetime as well as time of armed conflict, but in terms of measures to combat the intentional destruction of cultural heritage it refers only to States. The Declaration includes provisions on the State responsibility when it "intentionally destroys or intentionally fails to take appropriate measures to prohibit, prevent, stop, and punish any intentional destruction of cultural heritage of great importance for humanity, whether or not it is inscribed on a list maintained by UNESCO or another international organization". ${ }^{207}$ While a Declaration does not have the same legal force among States as a treaty or convention, in United Nations practice, a Declaration is a means of defining norms, that are likely to be abided by States and "in so far as the expectation is gradually justified by State practice, a declaration may by custom become recognized as laying down Rules binding upon States". ${ }^{208}$

Under the ICL, unlawful acts against cultural property may constitute war crimes, only if a nexus between the committed acts and an armed

${ }^{206}$ UNESCO Declaration concerning the International Destruction of Cultural Heritage, UNESCO, (Oct. 17, 2003), available at http://portal.unesco.org/en/evphp-

URL_ID $=17718 \&$ URL_DO=DO_TOPIC\&URL_SECTION=201.html. For a critique of the Declaration see: Francesco Francioni, The Human Dimension of International Cultural Heritage Law: An Introduction, The European Journal of International Law Vol. 22 no. 1, EJIL 2011. Available at: https://academic.oup.com/ejil/article/22/1/9/436703

${ }^{207}$ See Article VI of the Declaration.

${ }^{208}$ See General introduction to the standard-setting instruments of UNESCO, available at: $\quad$ http://portal.unesco.org/en/evphpURL ID $=23772 \& U R L \_D O=D O \_$TOPIC\&URL SECTION=201.html\#name= $\underline{3}$. 


\section{Enhancing International Law with Respect to The Protection of Cultural Property in Times of Armed Conflict: A Comparative Analysis}

Salwa Youssef Elekyabi

مجلة علمية محكمة المجلة القانونية (مجلة متخصصة في الدراسات والبحوث القانونية)

conflict exists. The Appeals Chamber, in Stakic case, has interpreted this nexus widely to include acts geographically remote from actual fighting, provided that they are committed "in furtherance or under the guise of the armed conflict". ${ }^{209}$ Therefore, it is not necessary that the war crimes be committed during actual hostilities, but rather there must be a close relation between the act and the armed conflict. This means that war crimes cannot be committed during peacetime. Unlike war crimes, crimes against humanity do not require a nexus between the committed acts and the armed conflict; they may occur in either peacetime or wartime. Under the description of crime against humanity, an attack against cultural property may amount to the crime of persecution, which is defined as an "intentional and severe deprivation of fundamental rights contrary to international law." However, in a crime of persecution, a nexus is required, as per Article $7 / 1 / \mathrm{h}$ of the ICC statute, between the crime of persecution and the commission of any crime within the statute. $^{210}$ Therefore, as in war crimes, crimes against humanity and of persecution cannot be committed during peacetime.

With regard to the IHL, the Common Article 2 of the 1949 Geneva Conventions states that the conventions "apply to all cases of declared war or of any other armed conflict which may arise between two or more of the High Contracting Parties, even if the state of war is not recognized by one of them". Therefore, the IHL is obviously applicable during times of armed conflict and occupation only and cannot be applied during peace. ${ }^{211}$

${ }^{209}$ Judgment, Stakic (IT-97-24-A), Appeals Chamber, 22 March 2006, section 342. Also, in Tadic the ICTY Appeals Chamber stressed that the offence has to be "closely related to the hostilities occurring in either parts of the territories controlled by the parties to the conflict". Prosecutor v Duško Tadić, ICTY (Appeals Chamber), Decision of 2 October 1995, para. 70.

${ }^{210}$ Roger O'Keefe, Cultural Heritage and International Criminal Law, in Cordonier Segger \& Jodoin (eds), Sustainable Development, International Criminal Justice, and Treaty Implementation (Cambridge: Cambridge University Press, 2013), pp.120-150 , Available at: $\mathrm{https://ssrn.com/abstract=3496737}$

211 In certain cases, the IHL may continue to be applied although the armed conflict has ended. For example, the ICTY, in Kunarac has held that the IHL continues to apply beyond the cessation of hostilities. Also, the UN Security Council resolution with regard to the territories occupied by Israel, including 
Based on the aforementioned, the protection of cultural property during times of armed conflict has received more attention and seems to be more developed than the protection during peacetime. Accordingly, the customary status of the norms for protecting cultural property during peacetime in international law is still evolving, while that of armed conflict has already been well-established. ${ }^{212}$ In the author's view, the protection of cultural property during peacetime complements the protection during armed conflict and vice versa. Any shortage in the protection during peacetime will have repercussions on the protection during armed conflicts. This is because the protection of cultural property is a continuous process that shouldn't cease to exist in a particular time. For example, the obligation to introduce the protection of cultural property in military regulations or instructions; or to mark cultural property with distinctive emblem, are essential in providing the protection whenever an armed conflict breaks out, though they are mainly applicable during peacetime. Conversely, protecting cultural property during armed conflict assists in helping communities postconflict to recover from the conflict's effects and rebuild their societies. ${ }^{213}$ Therefore, the connection between the protection of cultural property during peacetime and during armed conflict is close. In the author's view, an approach towards a wide interpretation of the rules applied in both times of armed conflict and peace, with a tendency towards the elimination of any dichotomy between the two regimes, is needed.

\section{IAC and NIAC}

Article 18 of the 1954 Hague Convention defines its scope of application by stating that it "shall apply in the event of declared war or of any other armed conflict which may arise between two or more of the High Contracting Parties, even if the State of war is not recognized by, one or

Jerusalem and the Golan Heights, has referred to a similar meaning. See, Kunarac, IT-96-23-T, Judgment of 22 Feb. 2001, at para. 467.

${ }^{212}$ Yaron Gottlieb, Criminalizing Destruction of Cultural Property, op.cit., pp.857-896.

${ }^{213}$ The Protection of Heritage and Cultural Diversity: A Humanitarian and Security Imperative in the Conflicts of the 21 st century, Background note to the International Conference "Heritage and Cultural Diversity at Risk in Iraq and Syria" UNESCO Headquarters, Paris 3 December 2014, a draft available at: http://en.unesco.org/system/files/iraqsyriaeventbackgroundnoteeng.pdf 


\section{Enhancing International Law with Respect to The Protection of Cultural Property in Times of Armed Conflict: A Comparative Analysis}

Salwa Youssef Elekyabi

مجلة علمبة محكمة المجلة القانونية (مجلة متخصصة في الدراسات والبحوث القانونية)

more of them". 214 The Convention is mainly addressed to the "High Contracting Party", therefore, it is mainly applied to IAC. However, brief mention to the NIAC has been introduced in Article 19 of the Convention, which is titled "conflicts not of an international character". This article requires that "parties" shall apply, as a minimum, the provisions related to the "respect" of cultural property. The obligation to respect cultural property, particularly Article 19 of the 1954 Hague Convention, has been recognized by the Appeals Chamber of the ICTY, in Tadić case, as being a part of International Customary Law. ${ }^{215}$

As argued by one scholar, ${ }^{216}$ the Convention includes other provisions that may apply during NIAC, beyond Article 19. For example: the marking of cultural property with the distinctive emblem (Articles 6, 1617); ensuring the impunity of cultural property under special protection (Articles 9-11); introducing the related provisions into the military regulations or instructions; fostering the spirit of respect for the culture and cultural property; establishing within the armed forces services or specialist personnel whose purpose is to secure respect for cultural property (Article 7); and provisions for protection of transports and personnel involved in cultural property protection (Articles 13-15). These articles are designed to be applied by States and some of them are related to peacetime; however, there is nothing in the Convention to prevent their application by ANSA or during NIAC in general, although there is no such obligation within the convention on this.

${ }^{214}$ Kevin Chamberlain commented on Articles 18 and 19 of the Hague Convention: "purely internal conflicts not involving the intervention of an outside power would not fall within the scope of Article 18 but would, provided they achieved the right level of intensity, fall under Article 19". Kevin Chamberlain, War and Cultural Heritage: A Commentary on The Hague Convention 1954 And Its Two Protocols, op.cit., at 14-16.

${ }^{215}$ ICTY, The Prosecutor v Dusko Tadić, Case No. IT-94-1-AR72, Decision on the Defence Motion for Interlocutory Appeal on Jurisdiction (Appeals Chamber), 2 October 1995, para 98.

${ }^{216}$ Cherif Bassiouni, Reflections on Criminal Jurisdiction in International Protection of Cultural Property, op.cit., at 294-96; Kevin Chamberlain, War and Cultural Heritage: A Commentary on The Hague Convention 1954 And Its Two Protocols, op.cit., at 54. 
Article 19/3 of the Convention states that UNESCO "may offer its services to the parties to the conflict" and that any such contact "shall not affect the[ir] legal status". ${ }^{217}$ In recent armed conflicts, for example the conflict in Syria, many international organizations including UNESCO have exerted efforts in providing their services to the employees of the DGAM and in areas under the government's control. However, no efforts were documented or found in any report with regard to reaching areas under the control of armed groups, although these areas are rich in cultural sites and monuments.

Generally, UNESCO and international humanitarian organizations can play a significant humanitarian role in saving cultural property, in accordance with the 1954 Hague Convention; although, they are still restricted when it comes to providing services to ANSA for two reasons. The first is that the language of the 1954 Hague Convention addressed only States Parties as the one who can call on UNESCO "for technical assistance in organizing the protection of their cultural property" and, thus, clearly excluding ANSA. The second is that UNESCO is prohibited by its Constitution from intervening in the internal affairs of States.

With regard to the applicability of the 1954 Hague Convention and its two protocols on the NIACs, it is noted that the Convention mentions clearly that Article 19 is applicable to the "conflicts not of an international character", although it did not specify exactly the moment in which the situation starts to be "not of an international character". The First Protocol has referred in its Article 10/c to Article 19 of the Convention, although the entire Protocol applies exclusively in situations of occupation. The 1999 Protocol applies to both IAC and NIAC, but it does not apply to "situations of internal disturbances and tensions, such as riots, isolated and sporadic acts of violence and other acts of a similar nature." 218 As per the historical decision of the ICTY of 2003, the application of all main principles originally meant to be applied during

${ }^{217}$ Article 19, paras 3-4 of the 1954 Convention.

${ }^{218}$ Article 22/2 of the Second Protocol. This definition tracks the exclusion found in Additional Protocol II to the 1949 Geneva Conventions, Article 1, Paragraph 2. For more see Cherif Bassiouni, Reflections on Criminal Jurisdiction in International Protection of Cultural Property, op.cit., at 294-96; Kevin Chamberlain, War and Cultural Heritage: A Commentary on The Hague Convention 1954 And Its Two Protocols, op.cit., at 52. 


\section{Enhancing International Law with Respect to The Protection of Cultural Property in Times of Armed Conflict: A Comparative Analysis}

Salwa Youssef Elekyabi

مجلة علمبة محكمة المجلة القانونية (مجلة متخصصة في الدراسات والبحوث القانونية)

IAC are extended to be applied during NIAC. ${ }^{219}$ Therefore, the Convention and its two Protocols could be applied on ANSAs, though the provisions of the Convention and both Protocols are not directly addressed to them.

Despite this, the prerequisite of the "armed conflict" is still valid, though cultural property can significantly be harmed during times of upsurges and internal disturbances. The starkest recent examples of such upsurges are those that resulted from the "Arab Spring", which had begun with peaceful anti-governmental demonstrations that soon turned into violent attacks against vital government premises including attacks against cultural property. In Syria, the violence quickly escalated and soon the situation was declared an armed conflict, ${ }^{220}$ unlike Egypt, in which the situation did not amount to an armed conflict and remained in the grey area of upsurges or internal turbulences. Reports have referred to damages of the cultural heritage in Egypt during that period. Thefts from the Egyptian Museum in Cairo ${ }^{221}$ and the Malawi Museum in Minya were reported, ${ }^{222}$ in addition to damages to other museums and

${ }^{219}$ See Decision on Interlocutory Appeal Challenging Jurisdiction in Relation to Command Responsibility, Prosecutor v Hadzihasanovic et al., ICTY, Appeals Chamber, 16 July 2003.

${ }^{220}$ In Syria there is a IAC between it and the different states composing the international coalition (the US, Belgium, Canada, Denmark, France, Germany, Italy, Jordan, Morocco, Netherlands, Saudi Arabia, Turkey, the United Arab Emirates and the United Kingdom), and a short-lived IAC between Syria and Israel and between Israel and Iran on the Syrian territory. This is in parallel to at least seven NIAC between Syria and armed groups or between the armed groups with each other. Aneesa Bellal, The War Report: Armed Conflicts in 2018.

${ }^{221}$ The Egyptian Museum in Cairo, by its location, was in the centre of the 2011 Egyptian upsurges. Reports have referred to the looting of around 1000 objects from the Egyptian museum on 28 January 2011. Egyptian Museum in Cairo - Thefts and Recoveries in 2011, Trafficking Culture, 21 August 2012. Available at: https://traffickingculture.org/encyclopedia/case-studies/egyptianmuseum-cairo-thefts-and-recoveries-in-2011/

${ }^{222}$ Experts from the United Nations cultural agency have confirmed that nearly all the collections of the Malawi National Museum in Upper Egypt have been looted. UNESCO mission confirms Egypt's Malawi museum ransacked, UN News 18 September 2013. Available at: 
repositories. $^{223}$ In such a situation, hypothetically, the rules of international law with respect to the protection of cultural property during peacetime will hold. For example, 1954 Hague Convention will be in effect only with respect to the provisions of safeguarding cultural property during peacetime.

In the author's view, the protection of cultural property is a continuous process which should start during peacetime and extend during times of unrest and times of armed conflict. The universal value of the cultural property and the new developments in contemporary armed conflicts justify the need for a holistic view with respect to the protection of cultural property. A new perspective for the protection of cultural property in all times would have many advantages. For example, the prohibition of the destruction of cultural property during peacetime would impact the concept of crimes against humanity, that would include the unlawful acts against cultural property as a distinct crime. In addition, the status of the ANSA would no longer affect the applicability of international law with respect to protection, which is a common problem in the IHL in general.

\section{Understanding the purposes of the protection}

The protection of cultural property per se has a humanitarian dimension, irrespective of the "human cargo" standard or the existence of the civilians within their confines. Although this protection is not seen as an independent legal "framework", it still has its own unique purposes by which it is distinguished from the IHL, IHRL, and ICL. In the author's view, understanding the purposes of the protection of cultural property during armed conflict should be the first step to be taken before suggesting ways for enhancement.

When describing the rationale behind protecting cultural property, François Bugnion, explains: ${ }^{224}$

https://news.un.org/en/story/2013/09/449342-unesco-mission-confirms-egyptsmalawi-museum-ransacked

${ }^{223}$ See, e.g., Monica Hanna, What Has Happened to Egyptian Heritage after the 2011 Unfinished Revolution?, 1:4 J. Eastern Mediterranean Archaeology \& Heritage Studies 371-75 (2013); Selima Ikram and Monica Hanna, Looting and Land Grabbing: The Current Situation in Egypt, 202 Bulletin Of The American Research Center In Egypt 34 (2013).

${ }^{224}$ François Bugnion, The origins and development of the legal protection of cultural property in the event of armed conflict, 50th anniversary of the 1954 


\section{Enhancing International Law with Respect to The Protection of Cultural Property in Times of Armed Conflict: A Comparative Analysis}

Salwa Youssef Elekyabi

المجلة القانونية (مجلة متخصصة في الدراسات والبحوث القانونية) لئة علمية محكمة

"Close your eyes and imagine Paris without Notre Dame, Athens without the Parthenon, Giza without the pyramids, Jerusalem without the Dome of the Rock, the Al-Aqsa Mosque and the Wailing Wall, India without the Taj Mahal, Cambodia without Angkor Wat and the Bayon, Peking without the Forbidden City, New York without the Statue of Liberty, Moscow without Red Square and St. Basil's Cathedral or Samarkand without the Registan and the Gur Emir, would we not all have lost part of our identities?".

These words simplify one purpose of protecting cultural property, which is preserving mankind's identity and the symbolic value of cultural property. This was affirmed in international criminal jurisprudence, finding that, when unlawful acts against cultural property reach a certain gravity, the loss transcends the material value of the property to touch the symbolic and spiritual significance of cultural property. In Jokic case, the ICTY found that destructing the old town of Dubrovnik, a site included in the UNESCO World Heritage List, has affected the "existence of [the old town's] population", which "was intimately intertwined with its ancient heritage". ${ }^{225}$ In another example, the prosecutor of the ICC, Fatou Bensouda, welcomed bringing Ahmad AlFaqi Al-Mahdi into justice, and explained that the charges brought against Al-Mahdi involved the destruction of irreplaceable historic monuments, which "falls into the category of crimes that destroy the roots of an entire people and profoundly and irremediably affect its social practices and structures ... [it is] a callous assault on the dignity and identity of entire populations, and their religious and historical roots". 226

Hague Convention for the protection of cultural property in the event of armed conflict.14-11-2004. available at: https://www.icrc.org/eng/resources/documents/article/other/65shtj.htm

${ }^{225}$ ICTY, The Prosecutor v Miodrag Jokić, Case No. IT-01-42/1-S, Judgment (Trial Chamber), 18 March 2004, paras 45, 53.

${ }^{226}$ Fatou Bensouda, "Statement of the Prosecutor of the International Criminal Court, Fatou Bensouda, at the Opening of the Confirmation of Charges Hearing in the Case against Mr Ahmad Al-Faqi Al Mahdi", ICC, 1 March 2016. Available at: https://www.icc-cpi.int/Pages/item.aspx?name=otp-stat-01-03-16 
In addition, cultural property connects new generations with their ancestors and demonstrates cultural coexistence. Some cultural property, such as: the Bridge at Mostar, the Mar Elian monastery of Syria and the shrine of Nebi Yunus in Mosul, have demonstrated the understanding and linkage between different religions and ethnicities, as such, these can assist in peace building after the conflict ends. The ICC prosecutor in $\mathrm{Al}$ Mahdi case affirmed this by stating that "cultural heritage plays a central role in the way communities define themselves and bond together, and how they identify with their past and contemplate their future". ${ }^{27}$ For example, the Umayyad Mosque in Damascus is a cultural building, which has been shared and identified as a place of worship by more than one religious group. ${ }^{228}$

Evidence from recent conflicts shows the close relationship between communities and their cultural property and demonstrates its value in their eyes. One example is that some ordinary people in Northern Mali managed to hide manuscripts beneath the floorboards of their homes to protect them during the 2012 attacks by extremist armed groups. Another example is the people who peacefully protested against the destruction of Sufi sites in Libya. ${ }^{229}$ In Syria, the director of the antiquities and museums of Palmyra sacrificed his life to protect the museum. ${ }^{230}$ The efforts exerted by the DGAM, archaeologists and local volunteers to inventor and transport cultural objects to a safe place ${ }^{231}$ are

${ }^{227}$ ICC, The Prosecutor v Ahmad Al Faqi Al Mahdi, Case No. ICC-01/1201/15-236, Reparations Order, 17 August 2017, para. 14.

${ }^{228}$ Rafi Grafman and Myriam Rosen-Ayalon, "The Two Great Syrian Umayyad Mosques: Jerusalem and Damascus",Muqarnas, Vol. 16, 1999.

229 "When Cultural Heritage is Under Attack, Human Rights are Under Attack" - UN Expert", UN News, 4 March 2016. Available at: https://news.un.org/en/story/2016/03/523612

${ }^{230}$ On 18 August 2015, Professor Khaled al-As'ad, the head director for antiquities and museums of Palmyra, Syria, was executed and his body hung in the main square of the city for having refused to reveal the location of archaeological treasures to the militia of the Islamic State of Syria and the Levant (ISIS). Andrea Pontecorvi, Is It Possible To Prosecute The Intentional Destruction Of Cultural Property By The Islamic State In Syria, Iraq And Libya?, 26 ILSA J Int'l \& Comp L 1, fall 2019, at. 2

231 By September 2015, all artefacts in Palmyra were transported to safe havens. Back then, the DGAM declared that $99 \%$ of museum artefacts has been transferred to a safe place. Silvia Perini and Emma Cunliffe, Towards a protection of the Syrian cultural heritage: A summary of the national and 


\section{Enhancing International Law with Respect to The Protection of Cultural Property in Times of Armed Conflict: A Comparative Analysis}

Salwa Youssef Elekyabi

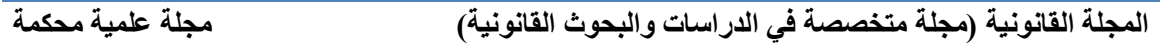

indicative of the value of cultural property to the local community, and this is what makes the impact of its loss so devastating to people and makes its protection so critical.

The introductory paragraphs of the 1954 Hague Convention add another purpose for protecting cultural property, by stating that the "damage to cultural property belonging to any people whatsoever means damage to the cultural heritage of all mankind, since every people makes its contribution to the culture of the world" and that "the preservation of the cultural heritage is of great importance for all peoples of the world". So, there is a global interest for people of the world in preserving cultural property of great importance, even if it is not in their territory. The ICTY affirmed this in Kordić \& Čerkez case; the prosecutor stated that "all of humanity is indeed injured by the destruction of a unique religious culture and its concomitant cultural objects." 232

Polina Mahnad explains that the convention's introductory paragraphs reflectthe approach of cultural internationalism, which sees cultural property as an "international public good" belonging to all people, unlike cultural nationalism, which claims that cultural property has an importance within the community to which it belongs and shall remain in the place of origin. However, these two approaches are not incompatible, but rather intertwined. It is perceivable that a cultural property object can belong to the humanity at large, and at the same time best to be preserved at the place of its origin. ${ }^{233}$ Though, the loss of a cultural property would definitely impact the local society more than the whole world. According to the the report of the UN Special Rapporteur on Cultural Rights, "the destruction of tombs of ancient Muslim saints in Timbuktu, a common heritage of humanity, is a loss for us all, but for

international responses Volume III (Sept 2014 - Sept 2015), available at: https://en.unesco.org/syrian-observatory/sites/syrian-

observatory/files/Towards-a-protection-of-the-Syrian-cultural-

heritage Vol3.pdf

${ }^{232}$ Prosecutor v Kordić \& Čerkez, Case No. IT-95-12/2-T, Trial Judgment, para. 207.

${ }^{233}$ Polina Levina Mahnad, Protecting cultural property in Syria: New opportunities for States to enhance compliance with international law? International Review of the Red Cross, Volume 99 Number 906 December 2017, pp.1037-1074. Available at: https://internationalreview.icrc.org/sites/default/files/906 10.pdf 
the local population it also means the denial of their identity, their beliefs, their history and their dignity". 234

In international prosecutions, the value of cultural property is inferred between the lines of prosecutors' statements and courts' decisions. In Krstic case, the prosecutor described the impact of the catastrophic destruction of cultural property as: "It's a community in despair; it's a community clinging to memories; it's a community that is lacking leadership; it's a community that's a shadow of what it once was"; he added that without cultural property, the community will only live in the biological sense, nothing more.

Furthermore, cultural property plays a significant role in helping people in post-conflict recover from the conflict's psychological trauma by rebuilding the fabric of societies and therefore sustaining long-lasting peace and security. ${ }^{236}$ On the contrary, depriving people from their right to access and enjoy cultural heritage can deepen their wounds and divisions, leaving them without a home to return, and in the worst scenarios threatens the presence of the community. ${ }^{237}$ Examples from the Spanish Civil War and, later, the Balkan Wars, show that refugees and displaced people refused to return to their home towns and villages unless the significant heritage sites were being rebuilt. ${ }^{238}$

Lastly, in some cases, preventing unlawful acts against cultural property may save the lives of people. The ICJ, in the case of Bosnia and Herzegovina v. Serbia and Montenegro, held that "where there is physical or biological destruction, there are often simultaneous attacks on cultural and religious property and symbols of the targeted group as well, attacks which may legitimately be considered as evidence of an

234 Report of the Special Rapporteur in the field of cultural rights, A/HRC/31/59 (Feb. 3, 2016), available at http://www.ohchr.org/Documents/Issues/CulturalRights/A-HRC-31-59 en.doc. ${ }^{235}$ Prosecutor v Radislav Krstic, ICTY Case No. IT-98-33-T, (2 August 2001), para 592. Available at: http://www.icty.org/x/cases/krstic/tjug/en/krstj010802e.pdf

236 The Protection of Heritage and Cultural Diversity: A Humanitarian and Security Imperative in the Conflicts of the 21st century, Background note to the International Conference "Heritage and Cultural Diversity at Risk in Iraq and Syria" UNESCO Headquarters, Paris 3 December 2014, a draft available at: http://en.unesco.org/system/files/iraqsyriaeventbackgroundnoteeng.pdf

237 Emma Cunliffe and others, The Destruction of Cultural Property in the Syrian Conflict, op.cit., pp.1-31.

${ }^{238}$ Marina Lostal and Emma Cunliffe, Cultural Heritage that Heals: Factoring in Cultural Heritage Discourses in the Syrian Peacebuilding Process, The Historic Environment: Policy and Practice, Vol. 7, No. 2-3, 2016, p. 250. Available at: https://papers.ssrn.com/sol3/papers.cfm?abstract id=2762259 


\section{Enhancing International Law with Respect to The Protection of Cultural Property in Times of Armed Conflict: A Comparative Analysis}

Salwa Youssef Elekyabi

المجلة القانونية (مجلة متخصصة في الدراسات والبحوث القانونية) لميةة محكمة

intent to physically destroy the group". ${ }^{239}$ In the same vein, it is worth quoting Raphael Lemkin's words: "Burning books is not the same as burning bodies ... but when one intervenes ... against mass destruction of churches and books, one arrives just in time to prevent the burning of bodies". 240

\section{Concluding Remarks}

As indicated in the introduction, this article aimed at exploring the division of international law with respect to the protection of cultural property during armed conflict, in order to assess how this may impact the understanding of "the protection of cultural property" and suggest ways for enhancement. As discussed throughout this Article, this division has a detrimental effect on the protection of cultural property, as well as, on the punishment and deterrence of the violations. Therefore, this article suggests three approaches for better understanding of the protection of cultural property during armed conflict.

First and foremost, the protection of cultural property during armed conflict should be viewed from a humanitarian perspective, rather than as a part of the operations during armed conflicts or hostilities that should be regulated by international law. The protection of cultural property is not a mere protection of stones or pieces of work for their beauty or uniqueness, but rather a protection of people's memories and identities. From this perspective, cultural property should remain protected at all times; likely, this would reduce the effects of the division in the protection.

Second, the protection of cultural property as provided in the 1954 Hague Convention could be enhanced by employing tools available in international law, which had been proven to be successful and had received wide international acceptance. These enhancements may include the following: (i) utilizing the listing system of the 1972 World Heritage Convention as the unified system to inventor and recognize cultural property of great importance and encouraging States to add their invaluable cultural property to this List; this will attain two benefits: declaring the importance of the property and marking the property immune from being attacked or used for military purposes; (ii) establishing safe havens or refuges to preserve endangered movable cultural property and keeping digital copies of documents and holograms for the sites and buildings of great importance as initiated by the UNESCO; (iii) developing the protection provided for the personnel

${ }^{239}$ ICJ, Case Concerning Application of The Convention on the Prevention and Punishment of the Crime of Genocide - Bosnia and Herzegovina v Serbia and Montenegro, Judgment, 26 February 2007, para. 344.

${ }^{240}$ Ibid. 
engaged in protecting cultural property; defenders of cultural property; and transports and appliances used for cultural property, through an IHRL perspective based on the right of the enjoyment of cultural rights. Third, the military necessity exception needs to be re-examined in light of recent developments, and a new concept for establishing "crimes against cultural property" may be developed. This Article suggests that this could be sought through the Customary International Law and the employment of the evolutionary interpretation of international treaties. According to the International Committee of the Red Cross (ICRC), Customary International Law "fills gaps left by treaty law in both international and non-international conflicts". ${ }^{241}$ From this perspective, the rules of international law with regard to the protection of cultural property may be re-examined to determine its validity to be a part of the Customary International Law. This will give such rules a broader applicability, thus, coping with the recent development in armed conflicts arena. With respect to the evolutionary interpretation, it is a method of interpretation used to determine the effect of the passage of time on treaties, through which the meaning of a certain word or terms in a treaty is interpreted according to the meaning it carries at the time of implementing the treaty not the time of its adoption. ${ }^{242}$ Adopting the evolutionary interpretation when interpreting the treaties related to the protection of cultural property is a tool for customizing the international obligations to cater for the new developments in armed conflicts. Concepts of IHL and IHRL are, by their nature, developed over time and change according to the circumstances of each case; therefore, the evolutionary interpretation would be beneficial. ${ }^{243}$

In conclusion, the failure of international law to protect cultural property during armed conflict is not due to the lack of laws, but rather to the lack of understanding the laws and reading them together. Adopting more laws will only aggravate the failure and would not necessarily guarantee better compliance. Therefore, in the author's view, employing the three aforementioned approaches would presumably contribute to achieving better understanding of the international law with respect to the protection of cultural property during armed conflict.

241 International Committee of the Red Cross, "Customary International Humanitarian Law," 29 October 2010, http://www.icrc.org/eng/war-andlaw/treaties-customary-law/customary-law/overview-customary-law.htm.

242 See generally; M. Fitzmaurice, "Dynamic (Evolutive) Interpretation of Treaties” (2008) Hague Yearbook of International Law, vol. 21., p.101.

${ }^{243}$ D. Rietiker, The principle of " Effectiveness" in the Recent Jurisprudence of the European Court of Human Rights: ITS different Dimensions and its consistency with public International law, Nordic J. Inl'L- 79,2010. 
Enhancing International Law with Respect to The Protection of Cultural Property in Times of Armed Conflict: A Comparative Analysis

Salwa Youssef Elekyabi

المجلة القانونية (مجلة متخصصة في الدراسات والبحوث القانونية) لمية علمية محمة

\section{List of References:}

(1) Articles:

- Alexander Orakhelashvili, The Interaction between Human Rights and Humanitarian Law: Fragmentation, Conflict, Parallelism, or Convergence? The European Journal of International Law Vol. 19 no. 1.

- Ana Filipa Vrdoljak, Cultural Heritage in Human Rights and Humanitarian Law (May 8, 2009), in O. Ben-Naftali, ed., International Human Rights and Humanitarian Law, Oxford University Press, 2011.

- Andrea Pontecorvi, Is It Possible To Prosecute The Intentional Destruction Of Cultural Property By The Islamic State In Syria, Iraq And Libya?, 26 ILSA J Int'1 \& Comp L 1, fall 2019.

- Anne Peters, The refinement of international law: From fragmentation to regime interaction and politicization, International Journal of Constitutional Law, Volume 15, Issue 3, July 2017.

- Ashlyn Milligan, Targeting Cultural Property: The Role of International Law, available at: https://jpia.princeton.edu/sites/jpia/files/2008-5.pdf

- Berenika Drazewska, The Human Dimension of the Protection of the Cultural Heritage from Destruction during Armed Conflicts, International Journal of Cultural Property, vol.22 (2015).

- Bennoune, K., "As-Salamu Alaykum? Humanitarian Law in Islamic Jurisprudence”, (1994) Vol.15, No 2, MICH. J. INT’1 L.

- Cara Libman, Preserving Culture During War: How to Prevent Terrorist Groups from Profiting from The Sale of Antiquities, 42 Suffolk Transnat'l L. Rev. 365.

- Caroline Ehlert (ed.), Prosecuting the Destruction of Cultural Property in International Criminal Law, Brill 2013.

- Christian Manhart, UNESCO's mandate and recent activities for the rehabilitation of Afghanistan's cultural heritage, IRRC June 2004 Vol. 86 No 854. 
- Cherif Bassiouni, Reflections on Criminal Jurisdiction in International Protection of Cultural Property, 10 SYR. J. INT'L L. \& COM. 281 (1983).

- Elizabeth Varner, The Art of Armed Conflicts: An Analysis of the United States' Legal Requirements towards Cultural Property under the 1954 Hague Convention, Creighton Law Review, Vol. 44, 2011.

- Emma Cunliffe and others, The Destruction of Cultural Property in the Syrian Conflict: Legal Implications and Obligations, International Journal of Cultural Property (2016).

- Francesco Francioni, The Human Dimension of International Cultural Heritage Law: An Introduction, The European Journal of International Law Vol. 22 no. 1, EJIL 2011.

- Gerhard Hafner, Pros and Cons Ensuing from Fragmentation of International Law, 25 MICH. J. INT'L L. 849 (2004).

- Jan Hladik, Marking of cultural property with the distinctive emblem of the 1954 Hague Convention for the Protection of Cultural Property in the Event of Armed Conflict, IRRC June 2004 Vol. 86 No 854.

- Jean-Marie Henckaerts \& Louise Doswald-Beck eds., Customary International Humanitarian Law (2 volumes), ICRC 2005.

- Jean-Marie Henckaerts, New Rules for the Protection of Cultural Property in Armed Conflict", International Review of the Red Cross, Vol. 81, No. 835, 1999.

- Jirí Toman, Cultural Property in War: Improvement in Protection, Commentary on the 1999 Second Protocol to the Hague Convention of 1954 for the Protection of Cultural Property in the Event of Armed Conflict, (2009).

- Jiri Toman, The Protection of Cultural Property in The Event of Armed Conflict: Commentary on The Convention For The Protection of Cultural Property in the Event of Armed Conflict and its Protocol, signed on 14 May 1954 in The Hague, and on other instruments of international law concerning such protection, Dartmouth (1996). 
Enhancing International Law with Respect to The Protection of Cultural Property in Times of Armed Conflict: A Comparative Analysis

Salwa Youssef Elekyabi

المجلة القانونية (مجلة متخصصة في الدراسات والبحوث القانونية) لمية علمية محمة

- Kanchana Wangkeo, Monumental Challenges: The Lawfulness of Destroying Cultural Heritage During Peacetime, 28 Yale J. Int'l L.

- Kevin Chamberlain, War and Cultural Heritage: A Commentary on The Hague Convention 1954 and Its Two Protocols (2d ed. 2013).

- Luke Moffett, A Bridge Too Far? Attacks against Cultural Property used as Military Objectives as War Crimes: The Prlić et al. case and the Mostar Bridge, International Criminal Law Review, June 2020.

- Lyndel V. Prott and Patrick J. O'Keefe, "Cultural Heritage" or "Cultural Property"?, available at: https://www.cambridge.org/core

- Maamoun Abdulkarim, Illicit trafficking of Syrian cultural property, Uniform Law Review, Volume 20, Issue 4, December 2015.

- Manlio Frigo, Cultural property v. cultural heritage: A “battle of concepts" in international law?, IRRC June 2004 Vol. 86 No 854.

- Marina Lostal, Challenges and Opportunities of the Current Legal Design for the Protection of Cultural Heritage During Armed Conflict, International Symposium on Cultural Heritage Protection in Times of Risk: Challenges and Opportunities, Yildiz Technical University, ICOMOS ICORP, Istanbul (Turkey) 2012.

- Mary Ellen O'Connell, Occupation Failures and the Legality of Armed Conflict: The Case of Iraqi Cultural Property, Working Paper No. 6, Ohio State University Moritz College of Law, 2004.

- Maja Sersic, protection of cultural property in time of armed conflict, Netherlands Yearbook of International Law, vol.26 (1996). 
- Micaela Frulli, The Criminalization of Offences against Cultural Heritage in Times of Armed Conflict: The Quest for Consistency, 22 EUR. J. INT'L L. (2011).

- Neil Brodie, Syria and its Regional Neighbors: A Case of Cultural Property Protection Policy Failure? International Journal of Cultural Propert, 2015.

- Nikolaus Thaddäus Paumgartner \& Raphael Zingg, The Rise of Safe Havens for Threatened Cultural Heritage, International Journal of Cultural Property, 25(3), 2018.

- Nobou Hayashi, Requirements of Military Necessity in International Humanitarian Law and International Criminal Law, Boston University International Law Journal 28 (2010).

- Nout Van Woudenberg, Protecting Cultural Property in Armed Conflict: An Insight into the 1999 Second Protocol to the Hague Convention of 1954 for the Protection of Cultural Property in the Event of Armed Conflict, edited by Liesbeth Lijnzaad, BRILL, 2014.

- Patty Gerstenblith, The Destruction of Cultural Heritage: A Crime Against Property or a Crime Against People?, 15 J. Marshall Rev. Intell. Prop. L. 336 (2016).

- Polina Levina Mahnad, Protecting cultural property in Syria: New opportunities for States to enhance compliance with international law?, ICRC (2017), 99 (3).

- Robert Cryer, Håkan Friman, Darryl Robinson, Elizabeth Wilmshurst, An Introduction to International Criminal Law and Procedure, Cambridge University Press, Jun 12, 2014.

- Roger O'Keefe and others, Protection of Cultural Property: Military Manual, UNESCO 2016.

- Roger O'Keefe, Protection of Cultural Property under International Criminal Law, 11 Melbourne Journal of International Law (2010).

- Roger O'Keefe, Cultural Heritage and International Criminal Law, in Cordonier Segger \& Jodoin (eds), Sustainable Development, International Criminal Justice, and Treaty 
Enhancing International Law with Respect to The Protection of Cultural Property in Times of Armed Conflict: A Comparative Analysis Salwa Youssef Elekyabi

المجلة القانونية (مجلة متخصصة في الدراسات والبحوث القانونية) لملة عية محكمة Implementation (Cambridge: Cambridge University Press, 2013).

- Serge Brammertz, Kevin C. Hughes, Alison Kipp and William B. Tomljanovich, Attacks against Cultural Heritage as a Weapon of War: Prosecutions at the ICTY", Journal of Criminal Justice, Vol. 14, No. 5, 2016.

- Sigrid Van der Auwera, International Law and the Protection of Cultural Property in the Event of Armed Conflict: Actual Problems and Challenges, The Journal of Arts Management, Law, and Society, 43:4.

- Yaron Gottlieb, Criminalizing Destruction of Cultural Property: A Proposal for Defining New Crimes under the Rome Statute of the ICC, Penn State International Law Review: Vol. 23: No. 4, (2005).

- Yaya J. Fanusie and Alexander Joffe, Monumental Fight: Countering the Islamic State's Antiquities Trafficking, Report of the Foundation for Defense of Democracies (Nov. 2015).

(2) Reports:

- Report of the Special Rapporteur in the field of cultural rights, A/HRC/31/59 (Feb. 3, 2016), available at: http://www.ohchr.org/Documents/Issues/CulturalRights/AHRC-31-59 en.doc.

- Report of the Independent Expert in the Field of Cultural Rights, UN. Doc. A/HRC/17/38 and Corr.1, 21 March 2011.

- Report of the Special Rapporteur in the field of cultural rights, A/HRC/31/59 (Feb. 3, 2016), available at:http://www.ohchr.org/Documents/Issues/CulturalRights/A -HRC-31-59 en.doc

- Report of the Special Rapporteur on extrajudicial, summary or arbitrary executions, Christof Heyns, Human Rights Council Twenty-third session, 9 April 2013. Available at: https://www.law.upenn.edu/live/files/3888-heyns-christofreport-of-the-special-rapporteur 
- Armed Non-State Actors and Landmines, Vol 1: A Global Report Profiling NSAS and their Use, Acquisition, Production, Transfer and Stockpiling of Landmines, PSIO Program for the Study of the International Organization(s) and Geneva Call. Available at: https://www.genevacall.org/wpcontent/uploads/2019/02/5.pdf

- Aneesa Bellal, The War Report: Armed Conflicts in 2018. Available at: https://www.geneva-academy.ch/joomlatoolsfiles/docman-files/The\%20War\%20Report\%202018.pdf

- Culture Under Fire: Armed Non-State Actors and Cultural Heritage in Wartime, Geneva Call, October 2018. Available at https://www.genevacall.org/wpcontent/uploads/2019/02/Cultural Heritage Study Final HI GHRES.pdf

- IHL Database, Customary IHL, ICRC. Available at: https://ihldatabases.icrc.org/customary-ihl/eng/docs/v1 rul rule144

- Association of Art Museum Directors, Protocols for Safe Havens for Works of Cultural Significance from Countries in Crisis, 28 September 2015.

- Final Report of the Commission of Experts Established pursuant to Security Council Resolution 780 (1992), Annex, 67-68, S/1994/674 (May 24, 1994), available at:http://www.icty.org/x/file/About/OTP/un_commission_of experts report1994 en.pdf

- UN Committee on Economic, Social and Cultural Rights (CESCR), General Comment No. 21, Right of Everyone to Take Part in Cultural Life (Article. 15, Para. 1a of the Covenant on Economic, Social and Cultural Rights), E/C.12/GC/21, 21 December 2009

(3) Judgments:

- ICJ, The Legality of the threat or Use of Nuclear Weapons, Advisory Opinion, ICJ Reports (1996). 
Enhancing International Law with Respect to The Protection of Cultural Property in Times of Armed Conflict: A Comparative Analysis Salwa Youssef Elekyabi

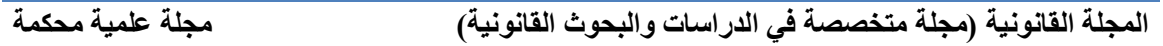

- ICJ, Legal Consequences of the Construction of the Wall in the Occupied Palestinian Territory, Advisory Opinion, ICJ Reports (2004).

- ICJ, Case Concerning Armed Activities in the Territory of the Congo (Congo v. Uganda), 19 December 2005, Judgment.

- ICJ, Case Concerning Application of The Convention on the Prevention and Punishment of the Crime of Genocide Bosnia and Herzegovina v. Serbia and Montenegro, Judgment, 26 February 2007.

- ICTY, Prosecutor v Strugar, Case No. IT-01-42-T (31 January 2005).

- ICTY, Prosecutor v Brđanin, Appeals Chamber Judgment, IT-99-36-A, (3 April 2007).

- ICTY, Prosecutor v Prlic et al., Judgment, 29 May 2013, Vol. II

- ICTY, Prosecutor v Miodrag Jokić, Trial Judgment, No IT01-42/1-S, Trial Chamber I, (18 March 2004).

- ICTY, Prosecutor v Dario Kordić and Mario Čerdez, Trial Judgment, No IT-95-14/2-T (26 February 2001).

- ICTY, Prosecutor v Strugar, Judgment, ICTY Trial Chamber, Case IT-01-42-T (Jan. 31, 2005).

- International Military Tribunal of Nuremberg, Trial Part 22 (22 August-1 October 1946), Judgment, 1 October 1946

- ICTY, Prosecutor v Pavle Strugar, Rule 98 Motion, No IT01-42-T, Trial Chamber II, ICTY (21 June 2004).

- ICTY, Prosecutor v Haradinaj, Case No. IT-04-84-84-T, 3 April 2008.

- ICTY, Prosecutor v Boskoski, Case No. IT-04-82, 10 July 2009. 
- ICTY, Prosecutor v Dusko Tadić, Appeals Chamber, Decision on the Defence Motion for Interlocutory Appeal on Jurisdiction, IT-94-1, 2 October 1995.

- ICTY, Decision on Interlocutory Appeal Challenging Jurisdiction in Relation to Command Responsibility, Prosecutor v. Hadzihasanovic et al., Appeals Chamber, 16 July 2003.

- ICTY, The Prosecutor v Miodrag Jokić, Case No. IT-0142/1-S, Judgment (Trial Chamber), 18 March 2004.

- ICC, Prosecutor v Ahmad Al Faqi Al Mahdi, ICC-01/1201/15, Judgment and Sentence, (27 September 2016).

- ICC, The Prosecutor v Ahmad Al Faqi Al Mahdi, Case No. ICC-01/12-01/15-236, Reparations Order, 17 August 2017.

(4) Treaties:

- The Lieber Code of 1863, Instructions for the Government of Armies of the United States in the Field, Series III, Vol. 3, sec. 124, General Orders no. 100. (Apr. 24, 1863), available at http://www.civilwarhome.com/liebercode.htm.

- The 1868 Declaration of Saint Petersburg, available at: https://ihl-

databases.icrc.org/applic/ihl/ihl.nsf/Treaty.xsp?action=open Document\&documentId=3C02BAF088A50F61C12563CD00 2D663B

- Convention (II) with Respect to the Laws and Customs of War on Land and Its Annex: Regulations Concerning the Laws and Customs of War on Land, July 29, 1899. Available at: http://www.icrc.org/ihl.nsf/WebPrint/150FULL?OpenDocument

- Convention (IV) respecting the Laws and Customs of War on Land and its annex: Regulations concerning the Laws and Customs of War on Land. The Hague, 18 October 1907. Available at: https://scannedretina.files.wordpress.com/2018/12/HagueConventions.pdf. 
Enhancing International Law with Respect to The Protection of Cultural Property in Times of Armed Conflict: A Comparative Analysis Salwa Youssef Elekyabi

المجلة القانونية (مجلة متخصصة في الدراسات والبحوث القانونية) لمية محكمة

- Treaty on the Protection of Artistic and Scientific Institutions and Historic Monuments (Roerich Pact), Washington, 15 April 1935, available at: https://ihldatabases.icrc.org/ihl/INTRO/325?OpenDocument

- Universal Declaration of Human Rights, 12 October 1948, UN Doc A/810 at 71 (1948).

- The Convention for the Protection of Human Rights and Fundamental Freedoms (European Convention on Human Rights or ECHR), 4 November 1950, in force 3 September 1953, ETS 5, 213 UNTS 221.

- The 1954 Convention and the two additional protocols. Available at: http://www.unesco.org/new/en/culture/themes/armedconflict-and-heritage/convention-and-protocols/statesparties/

- International Covenant on Economic, Social and Cultural Rights, 16 December 1966, 993 UNTS 3.

- The 1969 European Convention on the Protection of the Archaeological Heritage.

- Illicit Trafficking of Cultural Property: Convention on the Means of Prohibiting and Preventing the Illicit Import, Export and Transfer of Ownership of Cultural Property 1970", available

at: www.unesco.org/new/en/culture/themes/illicit-traffickingof-cultural-property/1970-convention/.

- The 1972 World Heritage Convention.

- The Protocol Additional to the Geneva Conventions of 1949 and relating to the Victims of International Armed Conflicts 1977.

- The Protocol Additional to the Geneva Conventions of 1949, and relating to the Victims of Non-International Armed Conflicts 1977. 
- The American Convention on Human Rights, 21 November 1969, in force 18 July 1978, OASTS No 36, 1144 UNTS 123.

- The 1985 Convention for the Protection of the Architectural Heritage of Europe.

- The African Charter on Human and Peoples' Rights, 27 June 1981, in force 21 October 1986, OAU Doc CAB/LEG/67/3 rev 5, 1520 UNTS 217.

- The 1995 UNIDROIT Convention on Stolen or Illegally Exported Cultural Objects.

- The ICC Rome Statute 1998.

- UNESCO Convention for the Protection of Underwater Cultural Heritage of 2 November 2001.

- UNESCO Convention for the Safeguarding of the Intangible Cultural Heritage and the UNESCO Declaration concerning the Intentional Destruction of Cultural Heritage, both of 17 October 2003. 